\title{
Political Song in Thomas Jefferson's Scrapbooks: A Multifaceted Commemoration of His Presidency
}

\author{
LAURA LOHMAN
}

\begin{abstract}
The political songs in a scrapbook volume attributed to Thomas Jefferson record a multi-faceted commemoration of a presidency that spans both personal and public commemoration practices at the local and national levels. To analyze the significance of political song at this nexus of personal and public commemoration, this article considers the scrapbook as both a physical artifact and as a commemorative work in progress. Creating the scrapbook during a transitional period in American collecting that was bound up with practices of reading, writing, and commemoration, Jefferson organized the political songs to bracket off a major period in his life while emphasizing public commemorative practices. Jefferson used the collection to track domestic political developments among a larger republican constituency and record Americans' responses to international struggles, including those that developed into the greatest challenges of his second term. Reading the political songs in conjunction with Jefferson's correspondence deepens our understanding of how music and politics relate in practices of commemoration, while considering the collection's temporality nuances our understanding of its intersections with Jefferson's concern with self-assessment, public assessment, and reputation.
\end{abstract}

In 1851, A. T. Laird donated a scrapbook containing songs to the University of Virginia. He noted, "Mr. Jefferson left in his library two scrap books, which it is said were compiled by his own hands during the term of his political administration." While the contents and provenance of one of these two scrapbooks remain unclear, Laird donated the other, which became one of four scrapbooks grouped by the University of Virginia library as the Jefferson-Randolph Family Scrapbooks. Through Laird's donated volume, we can consider how an early American used political song in practices of textual collection and commemoration during a trying period. While such political verse has often been derided on aesthetic grounds, ${ }^{2}$ examining the political songs highlights how this scrapbook sits at an intriguing intersection of personal and public commemoration. To explore the meanings of political song at that intersection, this article considers the scrapbook as physical artifact and commemorative work in progress. True to the elusiveness of "the real inner Jefferson," the political songs both invite and frustrate attempts to answer why Jefferson selected songs and constructed the collection as he did. ${ }^{3}$ The scrapbook thus echoes interpretive challenges posed by artifacts such as Louis Armstrong's deathbed memoir and opens itself to numerous readings. ${ }^{4}$

\footnotetext{
${ }^{1}$ Robert M. S. McDonald, Confounding Father: Thomas Jefferson's Image in His Own Time (Charlottesville: University of Virginia Press, 2016), 236, https://doi.org/10.3998/mpub.11560559.

${ }^{2}$ Donald H. Stewart, The Opposition Press of the Federalist Period (Albany: State University of New York Press, 1969), 2168; McDonald, Confounding Father, 193; Dumas Malone, Jefferson the President: First Term, 1801-1805 (Boston: Little, Brown and Company, 1970), 16; Dumas Malone, Jefferson the President: Second Term, 1805-1809 (Boston: Little, Brown and Company, 1974), 147.

${ }^{3}$ Jack N. Rakove, "Thomas Jefferson in the Twenty-First Century," in A Companion to Thomas Jefferson, ed. Francis D. Cogliano (Malden, MA: Wiley-Blackwell, 2012), 555, https://doi.org/10.1002/9781444344639.ch33.

${ }^{4}$ Dalton Anthony Jones, "Louis Armstrong's 'Karnofsky Document': The Reaffirmation of Social Death and the Afterlife of Emotional Labor," Music and Politics 9, no. 1 (Winter 2015), https://doi.org/10.3998/mp.9460447.0009.105.
} 


\section{Music and Politics Winter 2022}

Examining the scrapbook's political songs is worthwhile for several reasons. First, it adds nuanced readings, attributions, and evidence to previous accounts of Jefferson's presidential-era scrapbooks. Complementing Jonathan Gross's reprinting of verse from the scrapbooks with brief commentary, Robert McDonald has addressed attributional evidence, such as Jefferson's handwriting, provenance including Jefferson's relatives, and organizational similarities to Jefferson's other collections. ${ }^{5}$ By closely examining the clippings in relation to Jefferson's correspondence and the paper used in Laird's volume, this study provides not only attributions for individual songs but also further support for McDonald's attribution of the scrapbooks to Jefferson.

Second, close consideration of the political songs in Laird's volume complements recent research on early American music and politics. Along with my own study of early American political music, historians Billy Coleman and Kirsten E. Wood have captured the political significance of concepts such as "harmony" and documented how music served as a "ground of contestation" and helped define the culture of politics as early Americans vied for political power. ${ }^{6}$ Complementing these national accounts, a close examination of this noteworthy musical object lets us consider what songs attracted an individual's attention and contemplate the meanings that the songs and the act of gathering them may have held for their collector.

Third, this study expands our understanding of the varied early American collections that preserve music. Early Americans and their colonial predecessors wrote music in manuscript books, while from 1830, binder's volumes gathered sheet music collections for parlor pianos. As Glenda Goodman and Candace Bailey have shown, such collections signified gentility and contributed to the construction of gender, class, race, and nation as they let amateurs learn, perform, and preserve music. ${ }^{7}$ While lending further weight to these authors' arguments for the importance of amateurs' involvement in musical practices, examining the scrapbook also exposes how music that circulated without notation in ephemeral newspapers was deemed important enough to collect, bind, and preserve. Newspapers circulated humorous, hortatory, and narrative songs and parodies, typically by presenting new lyrics with the title of the tune to which they were to be sung or by leaving the tune up to the reader's choice or inference from the text's structure or refrain. All of these song types are represented in the scrapbook. Much like partisan newspapers, the clipped songs were curated to emphasize songs of one party, in this case the Republicans. ${ }^{8}$

Commemoration, as Barry Schwartz has explained, is one approach to "historical remembering." Unlike "chronicling," which records events and their sequences, commemoration is evaluative. Schwartz captures the essence of commemoration as seen in public rituals marking significant anniversaries:

\footnotetext{
${ }^{5}$ Jonathan Gross, ed. Thomas Jefferson's Scrapbooks: Poems of Nation, Family, and Romantic Love Collected by America's Third President (Hanover, NH: Steerforth Press, 2006); McDonald, Confounding Father, 235-42.

${ }^{6}$ Laura Lohman, Hail Columbia! American Music and Politics in the Early Nation (New York: Oxford University Press, 2020), https://doi.org/10.1093/oso/9780190930615.001.0001; Billy Coleman, Harnessing Harmony: Music, Power, and Politics in the United States, 1788-1865 (Chapel Hill: University of North Carolina Press, 2020), https://doi.org/10.5149/northcarolina/9781469658872.001.0001; Kirsten E. Wood, “Join with Heart and Soul and Voice': Music, Harmony, and Politics in the Early American Republic," American Historical Review 119, no. 4 (October 2014): 1083-116, https://doi.org/10.1093/ahr/119.4.1083.

${ }^{7}$ Glenda Goodman, Cultivated by Hand: Amateur Musicians in the Early American Republic (New York: Oxford University Press, 2020), https://doi.org/10.1093/oso/9780190884901.001.0001; Candace Bailey, "Binder's Volumes as Musical Commonplace Books: The Transmission of Cultural Codes in the Antebellum South," Journal of the Society for American Music 10, no. 4 (November 2016): 446-69, https://doi.org/10.1017/S1752196316000353; Candace Bailey, Unbinding Gentility: Women Making Music in the Nineteenth-Century South (Urbana: University of Illinois Press, 2021), https://doi.org/10.5406/i.ctv1k03s8m.

${ }^{8}$ Lohman, Hail Columbia!; Laura Lohman, “More Truth than Poetry': Parody and Intertextuality in Early American Political Song," MUSICultures 47 (2020): 34-62.
} 
commemoration "celebrates and safeguards the ideal. Commemoration lifts from an ordinary historical sequence those extraordinary events which embody our deepest and most fundamental values."

Consistent with Schwartz's elaboration, much scholarship addressing music and commemoration has focused on public forms of commemoration. For example, Sabelo J. Ndlovu-Gatsheni and Wendy Willems explored how early twenty-first century televised music festivals commemorating historical events and individuals marked moments in Zimbabwe's struggle for independence, popularized a specific national identity, defined political opponents, and urged youth to oppose domestic "imperialist" forces amid the ruling party's revival of cultural nationalism. ${ }^{10}$ Other studies have focused on the commemorative significance of specific compositions, their often mixed reception, and their ability to expose the contested nature of public memory following war and trauma in twentieth-century Europe. ${ }^{11}$ More recently, musicologists and ethnomusicologists have addressed the performative dimension of commemoration with a focus on reenactment and trauma. Contributors to Performing Commemoration demonstrated how performed remembrance can fulfill numerous social functions in varied global contexts, including the pursuit of justice, the erasure of injustice, the claiming of territory, and the shaping of memory. ${ }^{12}$ In contrast, this study addresses another sphere in which music can be used for commemoration- the personal sphereby considering a physical object constructed in a way that suggests its creator was its primary intended audience. $^{13}$

While elsewhere I have used Jefferson's presidential-era scrapbooks to illustrate the use of digital and archival tools for those beginning to research early American music, here my focus is how one of the scrapbooks captures the intersection of personal and public commemoration. ${ }^{14}$ Public rituals commemorating important historical events and people were a noteworthy subset of celebrations and street theater throughout the early Republic. ${ }^{15}$ After the Revolutionary War, Americans in towns large and small regularly organized public rituals that commemorated important events in the nation's pursuit of independence, the erection of physical monuments, the abolition of the Atlantic slave trade, and the birthdays, inaugurations, and deaths of presidents. Paralleling many of Ndlovu-Gatsheni and Willems's findings, such commemorations were understood to shape Americans' sentiments and were used to

\footnotetext{
${ }^{9}$ Barry Schwartz, "The Social Context of Commemoration: A Study in Collective Memory," Social Forces 61, no. 2 (December 1982): 377.

${ }^{10}$ Sabelo J. Ndlovu-Gatsheni and Wendy Willems, "Making Sense of Cultural Nationalism and the Politics of Commemoration under the Third Chimurenga in Zimbabwe," Journal of Southern African Studies 35, no. 4 (December 2009): 945-65, https://doi.org/10.1080/03057070903314226.

${ }^{11}$ Eva Moreda-Rodríguez, "Musical Commemorations in Post-Civil War Spain: Joaquín Rodrigo’s Concierto Heroico," in Twentieth-Century Music and Politics: Essays in Memory of Neil Edmunds, ed. Pauline Fairclough (New York: Routledge, 2016), 177-89; James G. Mansell, "Musical Modernity and Contested Commemoration at the Festival of Remembrance, 1923-1927," The Historical Journal 52, no. 2 (June 2009): 433-54, https://doi.org/10.1017/S0018246X09007535.

${ }^{12}$ Annegret Fauser and Michael A. Figueroa, eds. Performing Commemoration: Musical Reenactment and the Politics of Trauma (Ann Arbor: University of Michigan Press, 2020).

${ }^{13}$ McDonald, Confounding Father, 129.

${ }^{14}$ Laura Lohman, “A Scrapbooking President and a Few Good Tunes: Researching Early American Musical Practices through the Jefferson-Randolph Family Scrapbooks," in Researching Secular Music and Dance in the Early United States: Extending the Legacy of Kate Van Winkle Keller, ed. Laura Lohman (New York: Routledge, 2021), 50-72, https://doi.org/10.4324/9781003039150-4.

${ }^{15}$ Laura Lohman, "Singing 'Past, Present and Future': Music in Early American Commemoration," Journal of the Society for American Music 15, no. 2 (May 2021): 192-223, https://doi.org/10.1017/S1752196321000031; Simon P. Newman, Parades and the Politics of the Street: Festive Culture in the Early American Republic (Philadelphia: University of Pennsylvania Press, 1997); David Waldstreicher, In the Midst of Perpetual Fetes: The Making of American Nationalism, 1776-1820 (Chapel Hill: University of North Carolina Press, 1997), https://doi.org/10.9783/9780812200478.
} 


\section{Music and Politics Winter 2022}

reinforce key values and articulate partisan narratives for multiple generations of Americans, often by connecting the historical moment being commemorated to contemporary political concerns. ${ }^{16}$

Although "personal commemoration" and "private commemoration" have been used to discuss the creation of busts and monuments to oneself, ${ }^{17}$ here the phrase denotes a primary sphere of social interaction in which commemoration may be carried out. As Guy Beiner has noted, the public rituals that have captured scholars' attention illustrate one of several "spheres of commemoration." Others include the private or personal sphere and intimate familial or friendship-based spheres. ${ }^{18}$ Personal commemoration may be captured in writing, as in the narratives of soldiers. ${ }^{19}$ Physical objects, such as clothing and souvenirs connected to significant personal or family experience, may also become focal points for personal commemoration and can extend commemoration from the personal to the family sphere. ${ }^{20}$ As scrapbooks emerged in the nineteenth century, they offered new objects for personally commemorating events, such as those important in one's life, family, or broader community.

Exploring interrelationships among these spheres of commemoration, ${ }^{21}$ this article analyzes how the scrapbook's political songs evidence a multifaceted commemoration of a presidency that sits at the intersection of personal commemoration and public commemoration practices at the local and national levels. To do so, the article first situates the scrapbook's political songs in a larger context of collecting, reading, writing, and commemoration practices. The second section examines how songs selected to open and close the political song grouping bracket off a major period in Jefferson's life as the focus of this personal commemorative record while also emphasizing public commemorative practices. The third section highlights how Jefferson used the collection to track significant domestic political developments among a larger republican constituency. The fourth section explores how his collection betrays concern with international struggles, including those that developed into the greatest challenges of his second term. The final section considers temporal dimensions of the scrapbook in relation to Jefferson's concern with selfassessment, public assessment, and reputation. Reading the political songs in conjunction with Jefferson's correspondence deepens our understanding of how music and politics relate in practices of commemoration. $^{22}$

\section{Collecting}

The scrapbook donated by Laird is presented in digitized format as one of four scrapbook volumes held by the University of Virginia Special Collections Library (Table 1). ${ }^{23}$ The octavo volumes are bound in

\footnotetext{
${ }^{16}$ Lohman, "Singing 'Past, Present and Future," 192-223.

${ }^{17}$ Malcolm Baker, "Public Fame or Private Remembrance? The Portrait Bust and Modes of Commemoration in EighteenthCentury England," in Memory \& Oblivion, ed. Wessel Reinink and Jeroen Stumpel (Dordrecht: Springer, 1999): 527-35, https://doi.org/10.1007/978-94-011-4006-5_60.

${ }^{18}$ Guy Beiner, "Negotiations of Memory: Rethinking 1798 Commemoration," The Irish Review 26 (Autumn 2000): 62, https://doi.org/10.2307/29735992.

${ }^{19}$ Alan Forrest, Napoleon's Men: The Soldiers of Revolution and Empire (London: Hambledon Continuum, 2006$), 22$.

${ }^{20}$ Beiner, "Negotiations of Memory," 65; John Morgan O'Connell, Commemorating Gallipoli through Music: Remembering and Forgetting (Lanham, MD: Lexington Books, 2018).

${ }^{21}$ Beiner, "Negotiations of Memory," 62.

22 Jones, "Louis Armstrong's 'Karnofsky Document"; Hon-Lun Yang, "Power, Politics, and Musical Commemoration: Western Musical Figures in the People's Republic of China 1949-1964,” Music and Politics 1, no. 2 (Summer 2007), https://doi.org/10.3998/mp.9460447.0001.205.

${ }^{23}$ The PDF file can be accessed at https://search.lib.virginia.edu/catalog/u2155055\#view-u2155055. Throughout this text, page numbers correspond to the digitized PDF file generated November 2, 2019, counting the first image of the scrapbooks as page 1 .
} 
leather, and the clippings contain varied prose and verse newspaper content. The clippings are pasted on repurposed materials, including pages from printed books, other printed matter, letters, and paper used to wrap letters. ${ }^{24}$ The four volumes resemble aspects of other nineteenth-century collections, such as the sentimental and religious verses collected in nineteenth-century American commonplace books of the Stockton family and the political content scrapbooked by British women abolitionists. ${ }^{25}$ Focusing on the large group of political songs that opens Laird's volume, this article considers the clipped songs, previous context(s) in which they circulated and were performed, the materials that carry the clippings, and the scrapbook's planning and construction.

\begin{tabular}{|l|l|l|}
\hline Pages in PDF & Main Content & Topics and Genres \\
\hline $1-332$ & Prose & $\begin{array}{l}\text { Methods of education, sensation, history, biography, } \\
\text { satire, geographic descriptions, religion, happiness, } \\
\text { idleness, family relations, farming, manufacturing, } \\
\text { medical treatments, and tales. }\end{array}$ \\
\hline $333-610$ & Prose & $\begin{array}{l}\text { Commemorations of July 4, March 4, Louisiana } \\
\text { Purchase, Masonic Feasts, Washington's birthday. } \\
\text { European politics, Tammany Society, presidential } \\
\text { addresses, anecdotes, levities, and assessments of } \\
\text { Jefferson. }\end{array}$ \\
\hline $611-852$ & Verse, largely poetry & $\begin{array}{l}\text { Epitaphs, epigrams, odes, satire, verse fables and stories, } \\
\text { verse addresses, elegies, songs. Politics, smoking and } \\
\text { drinking, seasons, times of day, hope, virtue, advice, } \\
\text { beauty, and poetry for, about, and by women. }\end{array}$ \\
\hline $853-1079$ & Verse, largely songs & $\begin{array}{l}\text { Songs, odes, cantatas, parodies, ballads, musical theatre, } \\
\text { sonnets, elegies, and other poetry. Politics, death, exile, } \\
\text { nature, human nature, Irish songs, and songs and poetry } \\
\text { for, about, and by women. }\end{array}$ \\
\hline
\end{tabular}

Table 1: Summary of contents of the digitized Jefferson-Randolph Family Scrapbooks.

The scrapbooks were made during a transitional period in American collections tied to memory and remembering. Extending a Renaissance practice, early Americans used commonplace books to collect prose and verse extracts from various texts, often copied under topical headings in bound volumes of blank pages. A commonplace book could help one remember quotations for use in conversation or provide pleasure in

\footnotetext{
${ }^{24}$ John W. Wayland, “The Poetical Tastes of Thomas Jefferson,” Sewanee Review 18, no. 3 (July 1910): 285. The original bound volumes are held by the University of Virginia Special Collections Library (MSS 5948, 5948-a, -b).

${ }^{25}$ Amanda Watson, "Shared Reading at a Distance: The Commonplace Books of the Stockton Family, 1812-40," Book History 18 (2015): 103-33, https://doi.org/10.1353/bh.2015.0006; Felicity James and Rebecca Shuttleworth, "Susanna Watts and Elizabeth Heyrick: Collaborative Campaigning in the Midlands, 1820-34," in Women's Literary Networks and Romanticism: "A Tribe of Authoresses," ed. Andrew O. Winckles and Angela Rehbein (Liverpool: Liverpool University Press, 2017), 47-72, https://doi.org/10.2307/j.cttlps32xn.7.
} 
reviewing verse. ${ }^{26}$ Americans also cut "scraps" and "scrapings" from printed texts and pasted them into volumes. The term "scrapbook" emerged around 1825 and was applied to Jefferson's collections the following year. ${ }^{27}$ Nineteenth-century scrapbooks often contained newspaper clippings, particularly of poetry. Scrapbook commonplace books and other fusions combined elements of diaries, scrapbooks, and commonplace books. ${ }^{28}$ Both nineteenth-century commonplace books and scrapbooks avoided the explicit topical organization of earlier commonplace books intended as "information retrieval systems" and increasingly held commemorative potential. ${ }^{29}$ Such collections often lacked explicit connections between items and displayed "collage aesthetics." 30

Illustrating the use of scrapbooks for personal commemoration, nineteenth-century scrapbooks enabled "a form of life writing that may or may not be chronological but records and preserves elements of life experience and memory cues." ${ }^{11}$ Men's collections included professional scrapbooks as "career autobiography" and memory albums of ephemera made by Union soldiers and medical practitioners. ${ }^{32}$ While collections like manuscript commonplace books may be read as archives, Kristin Gilger stresses that extending such a reading to scrapbooks can obscure the "significance of scrapbook-making as a distinct and creative curatorial practice." Through that creative practice, scrapbookers like Jefferson could construct particular histories "by editing and rearranging items that vary in time, space, voice, and location." 33

That newspaper clippings filled some of the earliest scrapbooks is unsurprising, for Americans avidly consumed newspapers. ${ }^{34}$ Daily newspaper-reading rituals shaped life stories like that of New York merchant and banker Edward Neufville Tailer, Jr., who inserted newspaper clippings in his diary. ${ }^{35}$ Newspaper reading

\footnotetext{
${ }^{26}$ Cristle Collins Judd, “Musical Commonplace Books, Writing Theory, and 'Silent Listening': The Polyphonic Examples of the 'Dodecachordon," Musical Quarterly 82, no. 3/4 (Autumn-Winter 1998): 483-84, 509-11, https://doi.org/10.1093/mq/82.3-4.482; Chris Goertzen, "Philander Seward's 'Musical Deposit' and the History of American Instrumental Folk Music," Ethnomusicology 26, no. 1 (January 1982): 1, https://doi.org/10.2307/851397; Victoria E. Burke, "Recent Studies in Commonplace Books,” English Literary Renaissance, 43, no. 1 (Winter 2013): 153-54, 158-59, https://doi.org/10.1111/1475-6757.12005.

${ }^{27}$ Leigh Ina Hunt, "Victorian Passion to Modern Phenomenon: A Literary and Rhetorical Analysis of Two Hundred Years of Scrapbooks and Scrapbook Making" (PhD diss., The University of Texas at Austin, 2006), 60, 77; "From Margaret Nicholas to Dabney S. Carr, 1826," https://tirs.monticello.org/letter/2175.

${ }^{28}$ Cary Nelson, "The Temporality of Commonplaces: A Response to Meredith McGill," American Literary History 19, no. 2 (Summer 2007): 375-76; Ellen Gruber Garvey, Writing with Scissors: American Scrapbooks from the Civil War to the Harlem Renaissance (New York: Oxford University Press, 2012), 3-18, https://doi.org/10.1093/acprof:oso/9780195390346.001.0001; Ronald J. Zboray and Mary Saracino Zboray, "Is It a Diary, Commonplace Book, Scrapbook, or Whatchamacallit?: Six Years of Exploration in New England's Manuscript Archives," Libraries \& the Cultural Record 44, no. 1 (2008): 101-23, https://doi.org/10.1353/lac.0.0055.

${ }^{29}$ Watson, "Shared Reading," 103, 105-7; Susan Stabile, Memory's Daughters: The Material Culture of Remembrance in Eighteenth-Century America (Ithaca, NY: Cornell University Press, 2018), 9-10; Anna Denov Rusk, "Collecting the Confederacy: The Civil War Scrapbook of Henry M. Whitney,” Winterthur Portfolio 47, no. 4 (Winter 2013): 267, https://doi.org/10.1086/673871.

${ }^{30}$ Kristin Gilger, "Otherwise Lost or Forgotten: Collecting Black History in L. S. Alexander Gumby's 'Negroana' Scrapbooks," African American Review 48, no. 1/2 (Spring/Summer 2015): 111, https://doi.org/10.1353/afa.2015.0004; Rusk, "Collecting the Confederacy," 279.

${ }^{31}$ Garvey, Writing with Scissors, 15.

${ }^{32}$ Rusk, "Collecting the Confederacy," 267, 271; Katherine Ott, "Between Person and Profession: The Scrapbooks of Nineteenth-Century Medical Practitioners," in The Scrapbook in American Life, ed. Susan Tucker, Katherine Ott, and Patricia P. Buckler (Philadelphia: Temple University Press, 2006), 29-41.

${ }^{33}$ Stabile, Memory's Daughters, 13, 15-16; Gilger, “Otherwise Lost or Forgotten,” 111.

${ }^{34}$ Charles G. Steffen, "Newspapers for Free: The Economies of Newspaper Circulation in the Early Republic," Journal of the Early Republic 23, no. 3 (Autumn 2003): 388-96, https://doi.org/10.2307/3595045; Thomas C. Leonard, News for All: America's Coming-of-Age with the Press (New York: Oxford University Press, 1995), 3-32.

${ }^{35}$ David Henkin, City Reading: Written Words and Public Spaces in Antebellum New York (New York: Columbia University Press, 1998), 131.
} 
was a ritual for Jefferson as well. He subscribed to dozens of newspapers during his presidency and kept substantial runs of some as bound volumes. ${ }^{36}$

In addition to newspaper reading, Laird's donation and the other three scrapbooks share features with Jefferson's personal collection practices. Between 1758 and 1780 Jefferson created commonplace books of legal, political, and literary material, and the songs in Laird's volume are consistent with Jefferson's longstanding interest in music. ${ }^{37}$ Jefferson recycled letter wrappers and paper scraps for writing drafts and notes, later binding such notes from his time as Secretary of State into the collection subsequently called "Anas." ${ }^{38}$ During his presidency, he clipped and sent poems to granddaughters Ellen Wayles Randolph (1796-1876), Anne Cary Randolph (1791-1826), and Cornelia Jefferson Randolph (1799-1871) for their verse collections when they were roughly five to eleven years old; he even sent Ellen a poem amid the bustle of his second inauguration. ${ }^{39}$ Also during his presidency, he gathered the New Testament sources that in retirement he would cut and assemble into The Life and Morals of Jesus of Nazareth. ${ }^{40}$

The scrapbooks also reflect organizing tendencies conspicuous in Jefferson's larger collections. In his libraries and other collections, Jefferson organized items through Francis Bacon's divisions of learning,

\footnotetext{
${ }^{36}$ Richard Beale Davis, "Jefferson as Collector of Virginiana," Studies in Bibliography 14 (1961), 135-37; Kevin J. Hayes, "The Libraries of Thomas Jefferson," in A Companion to Thomas Jefferson, ed. Francis D. Cogliano (Malden, MA: WileyBlackwell, 2012), 335-37, 340, 342, 344, https://doi.org/10.1002/9781444344639.ch21; McDonald, Confounding Father, 128; "From Thomas Jefferson to Thomas Mann Randolph, 28 January 1800," Founders Online, National Archives, https://founders.archives.gov/documents/Jefferson/01-31-02-0290; "From Thomas Jefferson to Henry Remsen, 31 December 1800," Founders Online, National Archives, https://founders.archives.gov/documents/Jefferson/01-32-02-0267;

“Memorandum Books, 1800," Founders Online, National Archives, https://founders.archives.gov/documents/Jefferson/0202-02-0010; “Memorandum Books, 1801," Founders Online, National Archives, https://founders.archives.gov/documents/Jefferson/02-02-02-0011; "List of Newspapers, [ca. 23 April 1802]," Founders Online, National Archives, https://founders.archives.gov/documents/Jefferson/01-37-02-0247; "From Thomas Jefferson to James Cheetham, 23 April 1802," Founders Online, National Archives, https://founders.archives.gov/documents/Jefferson/01-37-02-0243; "Memorandum Books, 1804," Founders Online, National Archives, https://founders.archives.gov/documents/Jefferson/02-02-02-0014; "Memorandum Books, 1806," Founders Online, National Archives, https://founders.archives.gov/documents/Jefferson/02-02-02-0016; "Memorandum Books, 1807," Founders Online, National Archives, https://founders.archives.gov/documents/Jefferson/02-02-02-0017; "Memorandum Books, 1808," Founders Online, National Archives, https://founders.archives.gov/documents/Jefferson/02-02-02-0018; "Memorandum Books, 1809," Founders Online, National Archives, https://founders.archives.gov/documents/Jefferson/0202-02-0019.

${ }^{37}$ Douglas L. Wilson, “Thomas Jefferson's Early Notebooks,” The William and Mary Quarterly 42, no. 4 (October 1985): 43850, https://doi.org/10.2307/1919028; K. Marie Stolba, "Music in the Life of Thomas Jefferson," American Music Teacher 25, no. 5 (April-May 1976): 6-12; Helen Cripe, Thomas Jefferson and Music (Charlottesville: University of Virginia Press, 1974). ${ }^{38}$ McDonald, Confounding Father, 129, 237-38; Matthew E. Crow, "History, Politics, and the Self: Jefferson's 'Anas' and Autobiography," in A Companion to Thomas Jefferson, ed. Francis D. Cogliano (Malden, MA: Wiley-Blackwell, 2012), 479, https://doi.org/10.1002/9781444344639.ch29.

39 "From Thomas Jefferson to Anne Cary Randolph, 18 April 1802," Founders Online, National Archives, https://founders.archives.gov/documents/Jefferson/01-37-02-0222; "From Thomas Jefferson to Ellen Wayles Randolph Coolidge, 4 March 1805," Founders Online, National Archives, https://founders.archives.gov/documents/Jefferson/99-01-021298; "From Thomas Jefferson to Ellen Wayles Randolph Coolidge, 21 May 1805," Founders Online, National Archives, https://founders.archives.gov/documents/Jefferson/99-01-02-1762; "To Thomas Jefferson from Ellen Wayles Randolph Coolidge, 20 July 1805," Founders Online, National Archives, https://founders.archives.gov/documents/Jefferson/99-01-022112; "From Thomas Jefferson to Ellen Wayles Randolph Coolidge, 24 November 1805," Founders Online, National Archives, https://founders.archives.gov/documents/Jefferson/99-01-02-2698; "From Thomas Jefferson to Ellen Wayles Randolph Coolidge, 1 March 1807," Founders Online, National Archives, https://founders.archives.gov/documents/Jefferson/99-01-02-5191; "From Thomas Jefferson to Cornelia Jefferson Randolph, 26 December 1808," Founders Online, National Archives, https://founders.archives.gov/documents/Jefferson/99-01-02-9406.

${ }^{40}$ Dickinson W. Adams, Jefferson's Extracts from the Gospels: The Philosophy of Jesus and The Life and Morals of Jesus (Princeton, NJ: Princeton University Press, 2014), 30-31.
} 
which he subdivided through "chronological or analytical arrangements." ${ }^{41}$ While newspaper issues gathered highly varied types of content ranging from price lists to legislation, constructing the scrapbooks entailed dividing this diverse content once again into groupings and subgroupings by genre, topic, and, in some cases, chronology. Laird's volume is organized as two large groups of political and sentimental song. Within each, further subdivisions are visible, such as a subgrouping of songs on the embargo dating to 1807 and 1808. Such topical and chronological arrangements also informed Jefferson's annual process of organizing and binding pamphlets. ${ }^{42}$

In sum, Laird's volume illustrates American and Jeffersonian collection practices tied up with reading, writing, and corresponding. Collections such as commonplace books and scrapbooks can be "studied as reflections of the sensibility of the compiler" as they capture the compiler's reading. ${ }^{43}$ However, scrapbooks' "clustered" and "mutable" nature can also hinder definitive interpretation. Instead, the "variability of historical ephemera" often preserved in scrapbooks can "draw attention to the multiplicity (and frequent indeterminacy) of potential narratives." ${ }^{44}$ While we cannot access with certainty the meaning that individual clippings held for Jefferson, we can explore clippings' possible meanings when read in conjunction with other clippings, contemporaneous texts, and Jefferson's correspondence. ${ }^{45}$ Particularly given Jefferson's predilection for organization, a logical starting point is the delineation of the political song grouping.

\section{Bracketing}

The group of over one hundred items clipped from American newspapers and pasted into the beginning of Laird's scrapbook almost entirely comprises political songs, along with some poetry on political subjects (pp. 869-943). The songs selected to open and close this grouping demarcate the grouping as a personal commemoration of the eight-year period defined by Jefferson's presidency. Bookending the political song grouping, the first and last songs circulated from 1801 to 1808 and were both printed under the title "Jefferson and Liberty." They encapsulate how Americans used public commemorative practices to express political values. Jefferson, in turn, used them to frame his own personal commemorative record of his two-term presidency. ${ }^{46}$ In addition to bracketing off this major period in Jefferson's life, these musical "bookends" foreground public support expressed in conjunction with Jefferson's inauguration, give attention to individuals he personally knew or corresponded with, and illustrate prominent aspects of public commemoration sustained during and initiated with his presidency.

The first several clippings capture the initial celebration and subsequent commemoration of Jefferson's inauguration. The first clipping (p. 869) was written by Scottish immigrant Alexander Wilson, a weaver, poet, violinist, flutist, and ornithologist who corresponded with Jefferson on their shared interest in

\footnotetext{
${ }^{41}$ Douglas Anderson, "Subterraneous Virginia: The Ethical Poetics of Thomas Jefferson," Eighteenth-Century Studies 33, no. 2 (Winter 2000): 233, https://doi.org/10.1353/ecs.2000.0003; Susan Manning, "Naming of Parts; Or, the Comforts of Classification: Thomas Jefferson's Construction of America as Fact and Myth," Journal of American Studies 30, no. 3 (December 1996): 348, 360; Hayes, "Libraries," 335-36, https://doi.org/10.1017/S0021875800024853.

${ }^{42}$ Wayland, "Poetical Tastes," 287-91; "From Thomas Jefferson to John Adams, 25 February 1823," Founders Online, National Archives, https://founders.archives.gov/documents/Jefferson/98-01-02-3357.

${ }^{43}$ Meredith L. McGill, "Common Places: Poetry, Illocality, and Temporal Dislocation in Thoreau's $A$ Week on the Concord and Merrimack Rivers," American Literary History 19, no. 2 (Summer 2007): 357, https://doi.org/10.1093/alh/ajm018.

${ }^{44}$ Gilger, "Otherwise Lost or Forgotten," 111.

${ }^{45}$ Katriel and Farrell, "Scrapbooks as Cultural Texts: An American Art of Memory," Text and Performance Quarterly 11, no. 1 (January 1991): 10-11, https://doi.org/10.1093/mq/82.3-4.482; McGill, “Common Places,” 362.

${ }^{46}$ Crow, "History, Politics, and the Self," 479.
} 
birds. ${ }^{47}$ Later reprinted as "written in 1800," Wilson's song circulated in newspapers in early 1801 as Congress was still determining the 1800 election's outcome after Republicans Jefferson and Aaron Burr both received seventy-three electoral votes ${ }^{48}$ Envisioning a Jefferson presidency, Wilson celebrated the end of the Federalists' "reign of terror" waged through the oppressive Alien and Sedition Acts that violated the first amendment of the Constitution. His chorus proclaimed, "Rejoice! Columbia's sons, rejoice! / To tyrants never bend the knee, / But join with heart, and soul, and voice, / For JEFFERSON and LIBERTY."49 Repeating this chorus fourteen times, Wilson's song provided the type of fanfare opening for the volume that Ott found in scrapbooks of nineteenth-century medical practitioners. ${ }^{50}$ The song was reprinted and performed throughout Jefferson's presidency to mark his March 4 inaugurations and July 4 within a larger set of public commemoration practices. ${ }^{51}$ Such public commemorations included processions through town, gatherings in meeting houses, convivial meals in outdoor and indoor settings, and military displays, with musical performances being integral to most of these segments. ${ }^{52}$

The third clipping preserves the lyrics of "The People's Friend" (p. 870, Figure 1). While the clipping notes the song's performance on July 4, it was written to mark Jefferson's inauguration just two weeks after Congress determined the election's outcome. The lyrics by Rembrandt Peale, son of Charles Wilson Peale, were set to music by the English immigrant inventor and instrument maker John Isaac Hawkins (17721854) (Figure 2). ${ }^{53}$ Both Peales and, later, Hawkins were among Jefferson's correspondents, and Rembrandt had already painted Jefferson's portrait in 1800. Charles promptly sent Jefferson a handbill of the Philadelphia March 4 inauguration performance and the music of "The People's Friend" for his daughter Martha's amusement at her Hawkins portable grand piano. ${ }^{54}$ The clipping attests to the commemorative performance of newly composed music in addition to simpler contrafacta of well-known singable tunes on anniversaries such as July 4. It also illustrates Jefferson's attention to Americans' use of the same songs to mark two occasions associated with him through the Declaration of Independence and his inauguration as the first Republican president. At the same time, and supporting McDonald's attribution of the scrapbooks to Jefferson after their attribution to his granddaughters, it reflects a valuing of expressions from those Jefferson knew. ${ }^{55}$

\footnotetext{
${ }^{47}$ Lohman, Hail Columbia!, 156-62.

48 "A Patriotic Song for the Glorious Fourth of March, 1801," Constitutional Telegraph (Boston), February 4, 1801, 1; “Jefferson and Liberty,” Farmers' Register (Troy, NY), December 18, 1804, 4.

${ }^{49}$ Capitalization, italics, punctuation, and spelling are retained from original sources in quotations and titles through this article.

${ }^{50}$ Ott, "Between Person and Profession," 36.

51 “A Patriotic Song," Kline's Carlisle Weekly Gazette, June 24, 1801, 4; "Jefferson and Liberty," American Mercury (Hartford, CT), July 1, 1802, 3; "Jefferson and Liberty," Weekly Wanderer (Randolph, VT), July 3, 1802, 4; "Jefferson and Liberty," Weekly Eastern Argus (Portland, ME), March 8, 1805, 3; "Jefferson and Liberty," Bee (Hudson, NY), June 4, $1805,2$.

${ }^{52}$ Lohman, "Singing 'Past, Present and Future," 192-223.

53 "Pieces to Be Sung at the German Reformed Church, on Wednesday, the 4th of March 1801," Manuscript/Mixed Material, The Thomas Jefferson Papers at the Library of Congress: Series 1: General Correspondence, https://www.loc.gov/item/mtjbib009726/; The Papers of Thomas Jefferson, ed. Barbara B. Oberg, vol. 33, 17 February to 30 April 1801 (Princeton, NJ: Princeton University Press, 2018), xlvii; John Thomas Scharf and Thompson Westcott, History of Philadelphia, 1609-1884, vol. 1 (Philadelphia: L. H. Everts \& Company, 1884), 508.

54 "To Thomas Jefferson from Charles Willson Peale, 8 March 1801," Founders Online, National Archives, https://founders.archives.gov/documents/Jefferson/01-33-02-0178. "From Thomas Jefferson to Thomas Mann Randolph, 19 March 1801," Founders Online, National Archives, https://founders.archives.gov/documents/Jefferson/01-33-02-0311; "From Thomas Jefferson to Thomas Mann Randolph, 4 June 1801," Founders Online, National Archives, https://founders.archives.gov/documents/Jefferson/01-34-02-0213; The Papers of Thomas Jefferson, vol. 33, xlvii-xlviii.

${ }^{55}$ Gross, Thomas Jefferson's Scrapbooks, 2; Andrew Burstein, The Inner Jefferson: Portrait of a Grieving Optimist (Charlottesville: University of Virginia Press, 1996), 173-74.
} 


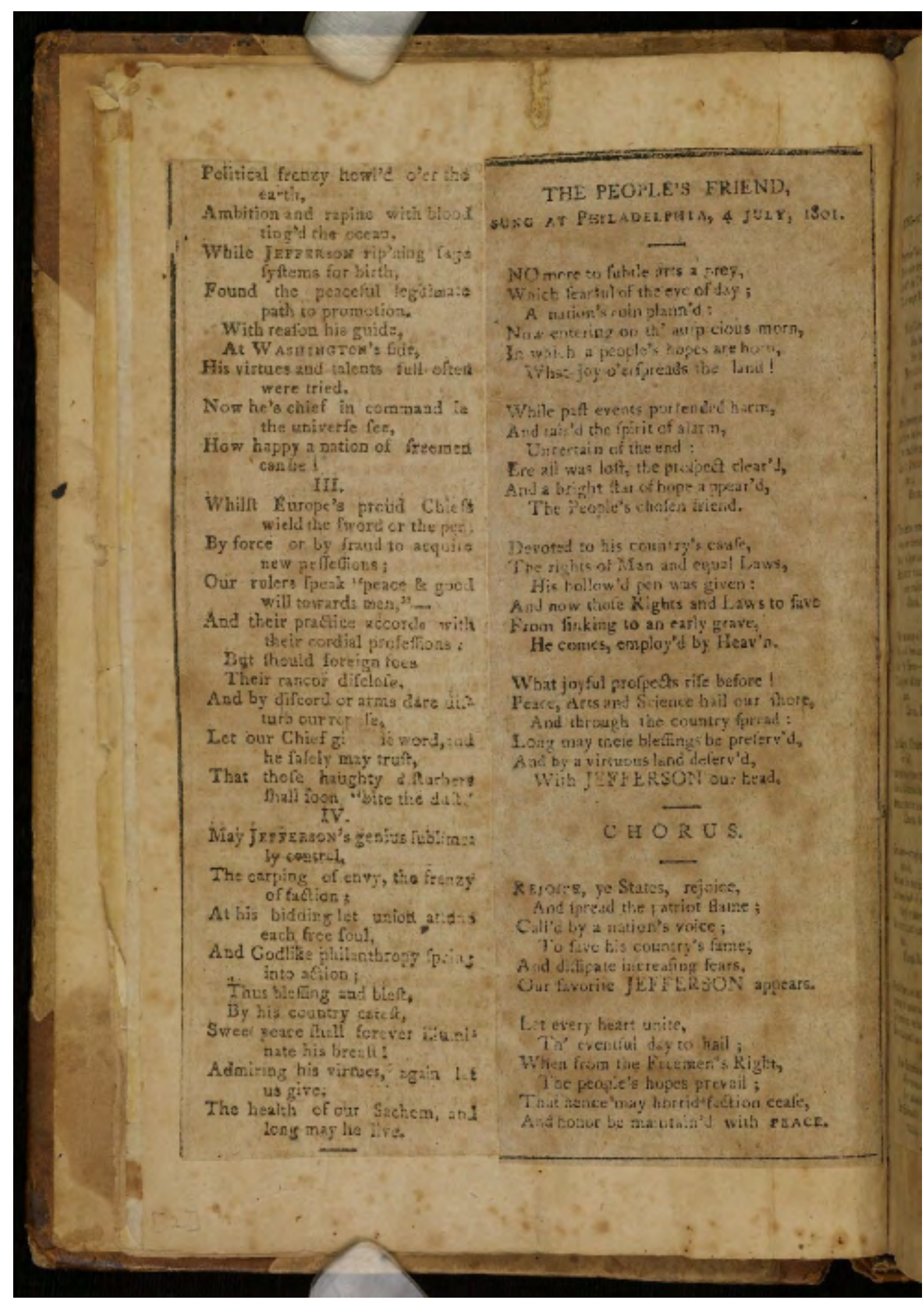

Figure 1: Scrapbook page containing part of the second and third newspaper clipping in Laird's volume: the continuation of a song sung in London on March 4, 1803, to commemorate Jefferson's inauguration and "The People's Friend," as reprinted following a July 4, 1801 performance in Philadelphia. University of Virginia Library. 


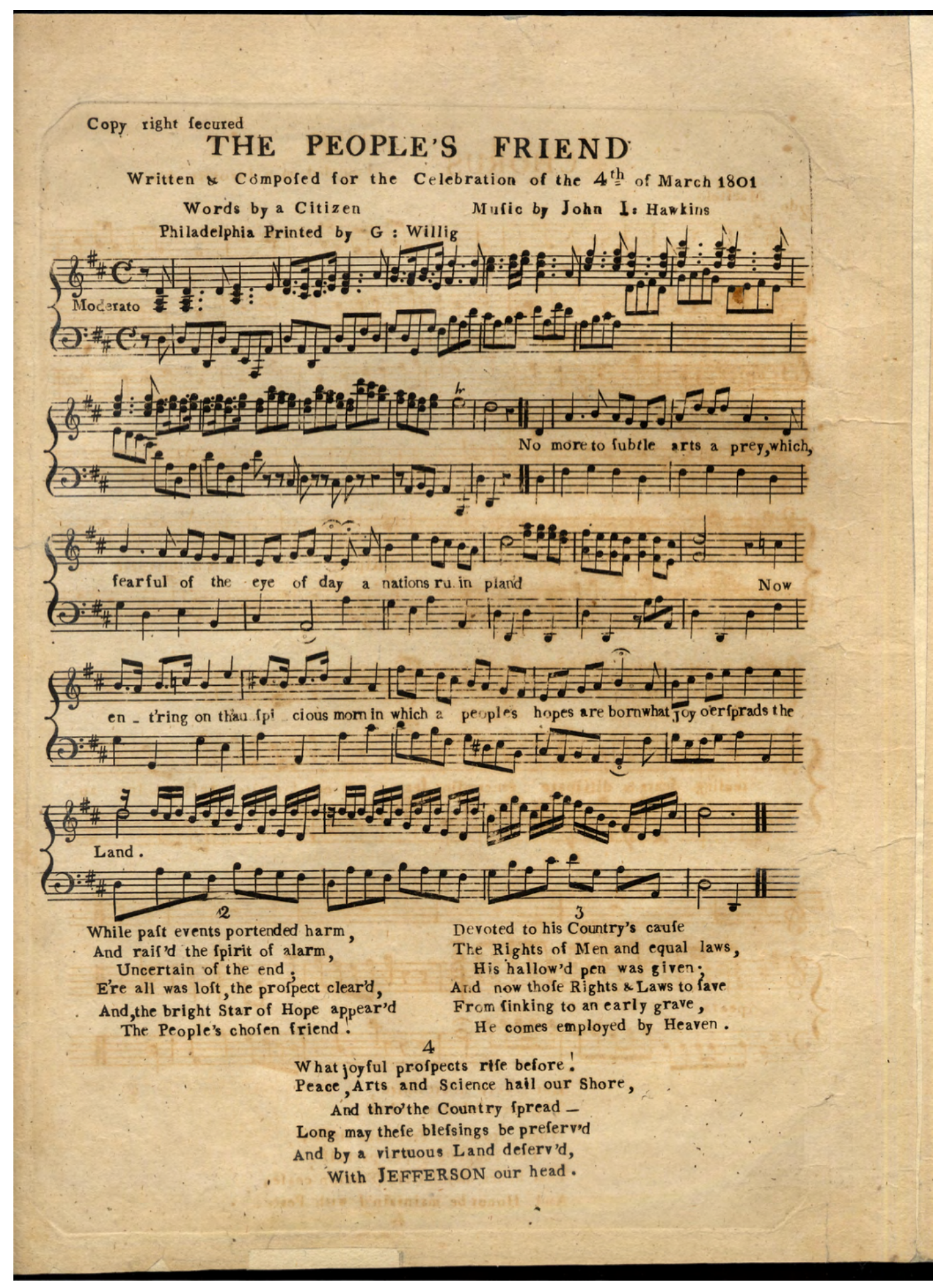

Figure 2: John Isaac Hawkins and Rembrandt Peale, "The People’s Friend.” Philadelphia: George Willig, 1801. Courtesy Lester S. Levy Sheet Music Collection, The Sheridan Libraries, Johns Hopkins University. 


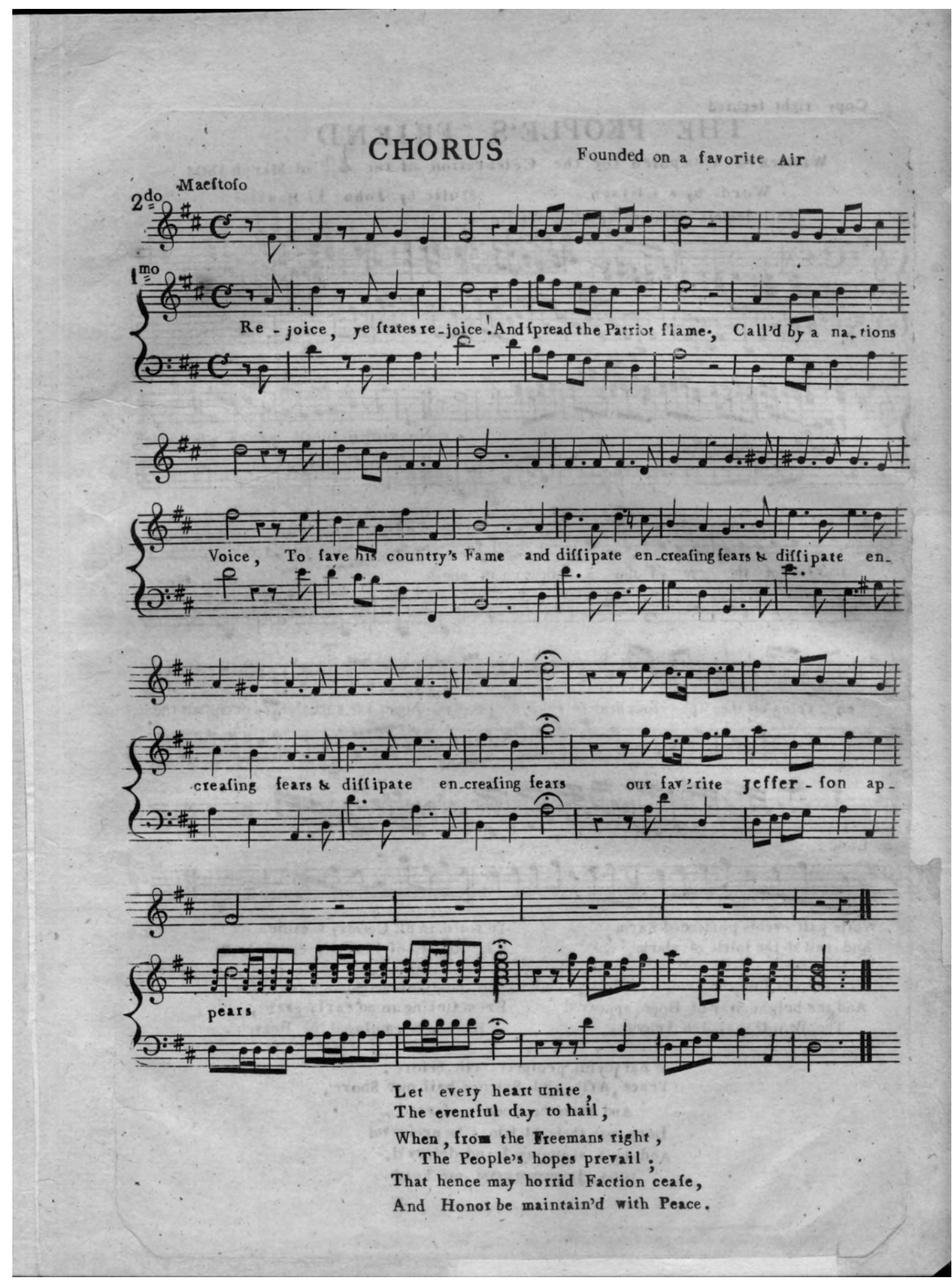

Figure 2: Continued.

Like Wilson's song and Peale and Hawkins' song, Americans performed the last song in the political song grouping (p. 943) to commemorate Jefferson's inauguration and July 4. As the clipping's headnote explained, "The following beautiful piece of composition, was sung in this city [Hartford], at the celebration of the 4TH OF JULY. Its origin is not known. . . It was written for the 4TH OF MARCH, the $2 \mathrm{~d}$ era of American Liberty—some slight alterations were made to accomodate it to the 1st era." ${ }^{56}$ Highlighting the

${ }^{56}$ American Mercury (Hartford, CT), September 15, 1808, 4. 
Declaration of Independence and Jefferson's inauguration as marking the nation's first and second eras of liberty, the headnote emphasized two pivotal events that turned on Jefferson's leadership. This last song illustrated Americans' sustained and increasingly complex use of contrafacta: ${ }^{57}$ the song was a contrafact of craftsman William Foster's "Jefferson and Liberty," a song distinct in music and lyrics from Alexander Wilson's song already discussed, which acquired the same title. Foster wrote his "Jefferson and Liberty" in mid-1800 as a contrafact of Robert Treat Paine's Federalist song "Adams and Liberty" to urge support for Jefferson's and other Republicans' election. ${ }^{58}$ The contrafact of Foster's song that captured Jefferson's attention circulated in 1802 to commemorate his inauguration, also under the title "Jefferson and Liberty." To commemorate his inauguration as a reversal of Federalist oppressive legislation and Anglophilic and monarchical tendencies, the contrafact conveniently wove a presidential lineage from Washington directly to Jefferson and omitted Adams altogether. Performing such a selective partisan narrative to commemorate July 4 extended separate Federalist and Republican commemorations of the day in the 1790s as partisan divisions emerged and then intensified during John Adams's term in the late 1790s. Then Americans had intimidated and shamed Republican adherents with songs like "Hail Columbia" and "Adams and Liberty" and escalated musical duels into physical blows. ${ }^{59}$ That Jefferson would have preserved so much political song is better understood when read against such intense musical expression of support for Federalists from 1798.

Between these bookend songs, many clippings reflect broad American commemorative practices spanning performance, writing, and printing. In addition to at least twenty-six clippings of July 4 verses, Jefferson clipped records of songs used to commemorate revolutionary war battles (p. 882), his inauguration (pp. 869, 905, 907, 943), and Washington's birthday (pp. 910-11). ${ }^{60}$ Songwriters and printers sometimes made explicit reference to the act of commemoration in lyrics and the headnotes introducing them (p. 931). An example occurred when Joseph Delaplaine of Cincinnati explained the connection to the revolutionary era in song, "The ensigns of liberty then were unfurl'd, / By each patriot son of this once happy world, / Each solemnly swore to live free or to die-- / And their freedom proclaim'd on the FOURTH OF JULY: / They swore to maintain the immortal decree, / That Columbia's brave sons shall forever be free. // To commemorate this, together we're met, / The birth day of Freedom, / we'll now celebrate, / And chaunt songs of praise to the manes [names] of the dead, / Who in Freedom's great cause have so cheerfully bled. / Who seal'd with their death, the immortal decree, / That Columbia's brave sons should forever be free" (pp. 874-75). The scrapbook volume that contains accounts of July 4 commemorations similarly demonstrates Jefferson's interest in preserving a record of public commemorative practices during his presidency. ${ }^{61}$

\footnotetext{
${ }^{57}$ Glenda Goodman, “Transatlantic Contrafacta, Musical Formats, and the Creation of Political Culture in Revolutionary America," Journal of the Society for American Music 11, no. 4 (November 2017): 392-419, https://doi.org/10.1017/S1752196317000359; Lohman, Hail Columbia!, 4-6 and passim.

${ }^{58}$ Lohman, Hail Columbia!, 154-55; "Jefferson and Liberty," Constitutional Telegraphe (Boston), August 20, 1800, 4; William C. Foster, Poetry on Different Subjects Written under the Signature of Timothy Spectacles (Salem, NY: John M. Looker, 1805), 115-17.

${ }^{59}$ Myron Gray, “A Partisan National Song: The Politics of 'Hail Columbia' Reconsidered,” Music and Politics 11, no. 2 (Summer 2017), https://doi.org/10.3998/mp.9460447.0011.201; Lohman, Hail Columbia!, 103-27. "Adams and Liberty” was the basis of many Federalists' and Republicans' contrafacta. The best-known contrafact is Francis Scott Key's “The Defense of the Fort M'Henry," which is still sung today as “The Star-Spangled Banner." See Lohman, Hail Columbia!, $248-54$.

${ }^{60}$ Songs written, printed, or performed to commemorate July 4 are found on pages 870, 873-76, 878-82, 884-86, 898-901, 904, 908, 914, 931-34, 938-39, 941. For more on music in such rituals, see Len Travers, Celebrating the Fourth: Independence Day and the Rites of Nationalism in the Early Republic (Amherst: University of Massachusetts Press, 1997), 41-54.

${ }^{61}$ Lohman, "A Scrapbooking President," 60-66.
} 


\section{Tracking}

Clever narratives like having the deceased Washington anoint Jefferson as president while omitting Adams suggest the highly partisan atmosphere in which Jefferson became president. Indeed, songs helped wage a "battle for the American mind" through competing partisan narratives. ${ }^{62}$ While McDonald interprets the scrapbooks as evidence of Jefferson's need for reassurance of the public's support of himself, reading the scrapbook volume along with Jefferson's correspondence clarifies how the political song grouping also commemorates the progress of a larger republican community. ${ }^{63}$

Jefferson's tracking of this community's progress can be seen in clippings related to Delaware (pp. 877-78), which he noted in 1801 was troubled by Republican division. ${ }^{64}$ "Progress of Federalism," clipped from the Wilmington Mirror, recounted the fate of Delaware congressman James Bayard (1767-1815) and his father-in-law through the transition from Adams's Federalist administration to Jefferson's Republican one (Figure 3). Focusing on the rapidly changing fates of prominent Federalists and "loaves and fishes," the giving of offices to loyal partisans, the song recounted how Bayard's father-in-law Richard Bassett (17451815) was made a judge at the end of Adams's presidency and unseated during Jefferson's first term when the Republican-dominated congress repealed the Judiciary Act of 1801, abolishing many new judicial seats. Like his father-in-law, Bayard's fate changed quickly. After opposing the Judiciary Act's repeal in early 1802, in the fall Bayard lost his bid for reelection to the House of Representatives. He was defeated by Republican Caesar Augustus Rodney, whom Jefferson had personally urged to run in April. Jefferson addressed Rodney as "the person who can unite the greatest portion of the republican votes, and the only one perhaps who can procure the dismission of your present representative to that obscurity of situation where his temper \& principles may be disarmed of all effect." Jefferson had commanded, "you are then, my dear Sir, bound to do this good office to the rest of America." ${ }^{65}$ Bayard's defeat was highly ironic, as his willingness to submit a blank vote in Congress's determination of the 1800 presidential election had catalyzed Jefferson's election on the thirty-sixth vote. ${ }^{66}$

\footnotetext{
${ }^{62}$ Burstein, Inner Jefferson, 243.

${ }^{63}$ McDonald, Confounding Father, 128, 130, 235.

${ }^{64}$ From Thomas Jefferson to Thomas McKean, 24 July 1801," Founders Online, National Archives, https://founders.archives.gov/documents/Jefferson/01-34-02-0477.

65 "From Thomas Jefferson to Caesar A. Rodney, 24 April 1802," Founders Online, National Archives, https://founders.archives.gov/documents/Jefferson/01-37-02-0261.

${ }^{66}$ John Ferling, Adams vs. Jefferson: The Tumultuous Election of 1800 (New York: Oxford University Press, 2004), 189-91.
} 


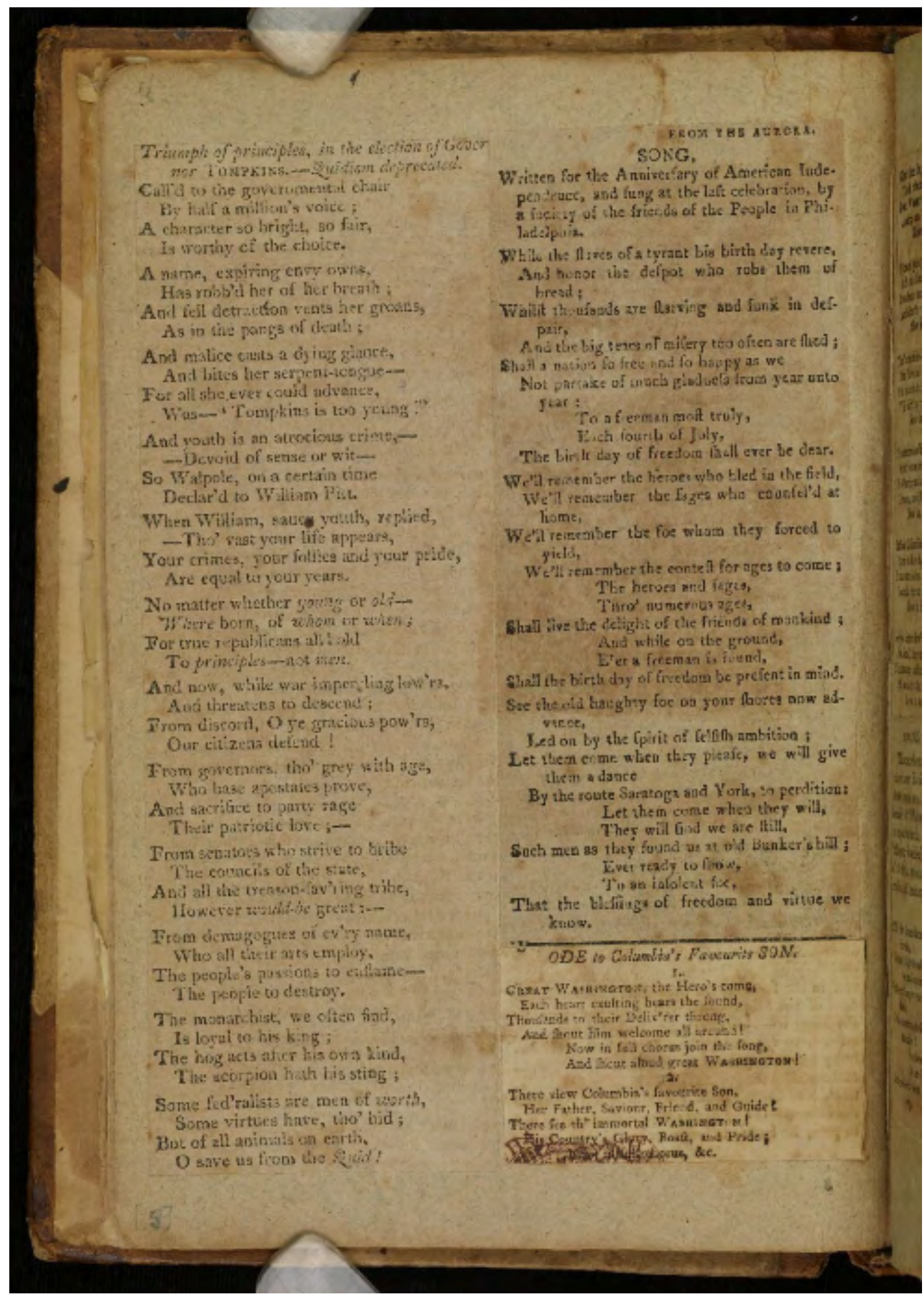

Figure 3: Two consecutive scrapbook pages contain clippings about internal Republican division, July 4, George Washington, and Delaware Federalists. University of Virginia Library. 


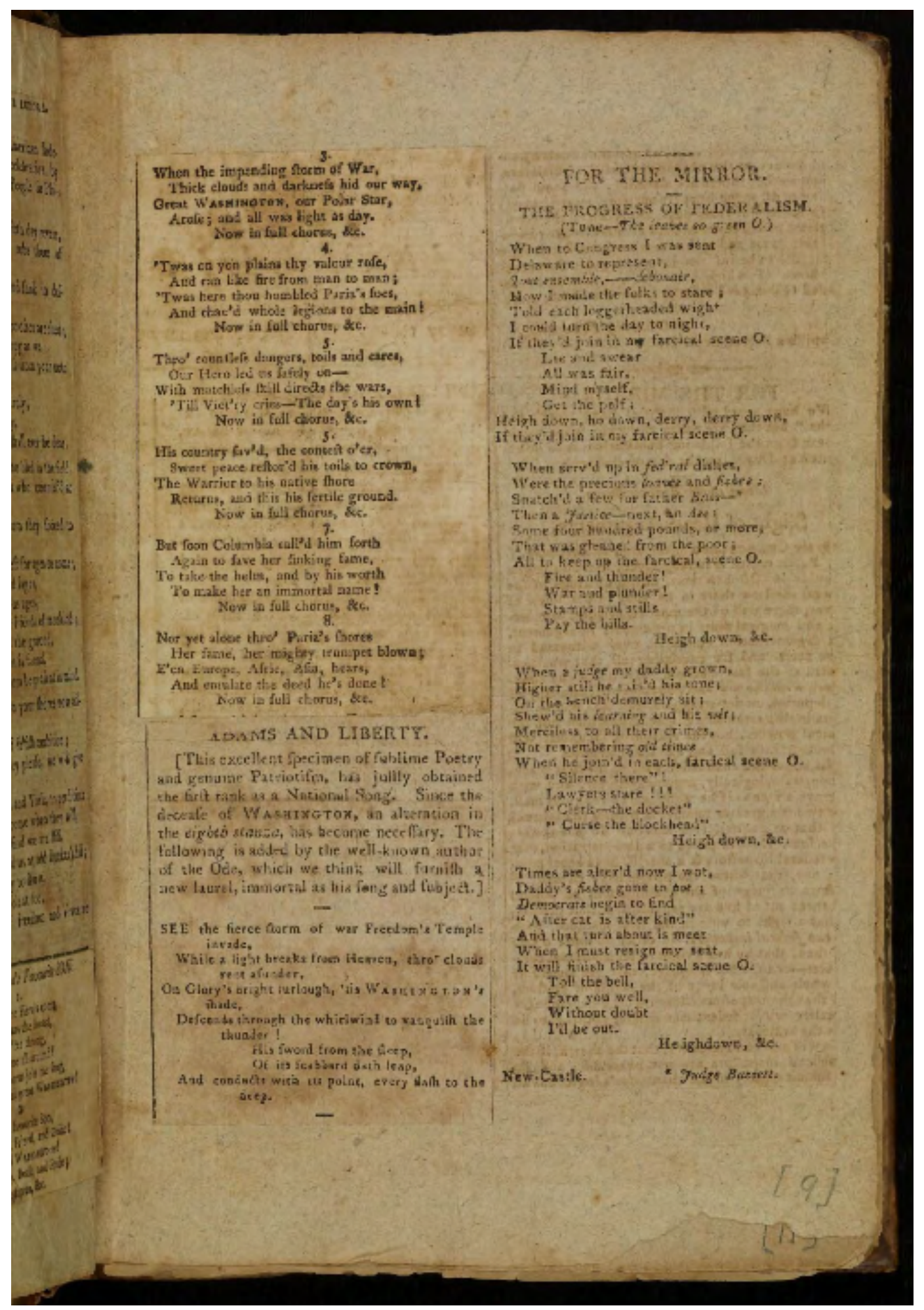

Figure 3: Continued.

Through clippings of songs written, printed, and performed in New England, Jefferson tracked Republicans' efforts to gain and retain support in this Federalist stronghold. Clipped songs tracked Republican victories in congressional and gubernatorial elections in Rhode Island and New Hampshire in 
1802 and 1805 (pp. 895, 899). ${ }^{67}$ This tracking mirrored Jefferson's correspondence. As he explained to Massachusetts Republican Elbridge Gerry in March 1804, "Vermont is solidly with us. R.I. with us on anomalous grounds; N.H. on the verge of the republican shore: Connecticut advancing towards it very slowly but with steady step; your state only uncertain of making port at all." ${ }^{98}$ Such attention to Republican ascendancy did not signal ignorance of Federalist song. Jefferson was familiar with Federalist songs by Robert Treat Paine and Jonathan Mitchell Sewall, whose work he pasted into the scrapbook (pp. 873, 898). Although he included almost no election-related Federalist lyrics in the volume, he singled out Paine's "Rule New England" when writing to John Langdon in 1802 about Massachusetts' Federalist inclination, concluding, "I am in hopes they will in time discover that the shortest road to rule is to join the Majority." 69 By 1805, John Adams could trace how Republican support had spread in Massachusetts through the political conversion of prominent members of leading families, and Jefferson was reelected by winning all Massachusetts's electoral votes and all states except Connecticut and Delaware. ${ }^{70}$ By 1808 , Jefferson, making a distinction between those Federalists who supported government based on republican principles and those who preferred one based on "English" models, would declare of the latter group, "federalism is dead, without even the hope of a day of resurrection."

In the political song grouping, Jefferson also tracked internal Republican division in the mid-Atlantic. After noting such schism in Delaware in 1801, Jefferson commented again on internal party discord in an 1804 regional assessment: "in the middle \& Southern states as great an union of sentiment has now taken place as is perhaps desireable. For as there will always be an opposition, I believe it had better be from avowed monarchists than republicans. New York seems to be in danger of republican division." 72 As Republicans split internally in New York and Pennsylvania, conservative Republicans who attracted Federalist supporters were dubbed "Quids," short for "tertium quids," meaning "third things."

Tracking this phenomenon, Jefferson clipped verse accounts of battles for these two states' governorships. One was William Ray's “Triumph of Principles” (p. 876, Figure 3), which addressed internal Republican division in New York in 1807, while "A Clodpole's Address to His Fellows" (p. 903) treated that in Pennsylvania in 1805. ${ }^{73}$ In the New York governor's race, the Clinton faction of New York Republicans led by George and DeWitt Clinton had nominated associate justice of the New York Supreme Court Daniel D. Tompkins. Tompkins defeated the Quids' candidate, incumbent Morgan Lewis, with 53\% of the vote. Ray's “Triumph of Principles” mocked the argument that Tompkins was too young, stressed the importance

\footnotetext{
${ }^{67}$ A similar emphasis on New England can be seen in the prose volume containing accounts of July 4 commemorations, including many from Connecticut, Rhode Island, and Massachusetts.

68 "From Thomas Jefferson to Elbridge Gerry, 3 March 1804," Founders Online, National Archives, https://founders.archives.gov/documents/Jefferson/01-42-02-0509.

69 "From Thomas Jefferson to John Langdon, 29 June 1802," Founders Online, National Archives, https://founders.archives.gov/documents/Jefferson/01-37-02-0560 .

70 "From John Adams to John Trumbull, 27 July 1805," Founders Online, National Archives, https://founders.archives.gov/documents/Adams/99-02-02-5089.

71 "From Thomas Jefferson to Richard Mentor Johnson, 10 March 1808," Founders Online, National Archives, https://founders.archives.gov/documents/Jefferson/99-01-02-7586; "From Thomas Jefferson to Michael Leib, 23 June 1808," Founders Online, National Archives, https://founders.archives.gov/documents/Jefferson/99-01-02-8204.

72 "From Thomas Jefferson to Thomas McKean, 24 July 1801," Founders Online, National Archives, https://founders.archives.gov/documents/Jefferson/01-34-02-0477; "From Thomas Jefferson to Elbridge Gerry, 3 March 1804," Founders Online, National Archives, https://founders.archives.gov/documents/Jefferson/01-42-02-0509.

73 "From Thomas Jefferson to Michael Leib, 12 August 1805," Founders Online, National Archives, https://founders.archives.gov/documents/Jefferson/99-01-02-2232; "From Thomas Jefferson to Andrew Ellicott, 1 November 1806," Founders Online, National Archives, https://founders.archives.gov/documents/Jefferson/99-01-02-4489.
} 
18 Music and Politics Winter 2022

of ending internal discord, and concluded, "O save us from the Quid.” Echoing Jefferson's sentiments, Ray maintained that a Federalist with some hidden virtues was better than the Quid. ${ }^{74}$

Beyond elections, clippings tracked progress seen in republican rituals, illustrating a shift from rituals echoing monarchical practices to those emphasizing republican values. Jefferson was shocked to find that "a preference of kingly, over republican, government, was evidently the favorite sentiment" on returning to the United States in 1790 after serving as Minister to France. ${ }^{75}$ He not only eliminated monarchical rituals from his own presidency, such as large presidential birthday celebrations and the levees established under Washington, but also tracked such shifts among a broader republican public. ${ }^{76}$ When Jefferson pasted in "His Majesty's Birth Day," British poet laureate Henry James Pye's ode for King George III's birthday in 1804, he placed it after verses marking the election and retirement of George Washington (pp. 896-98), as if to trace how far the nation had come in establishing new republican values and rites. As documents of praiseworthy American republican progress, clippings about Washington can be interpreted as highlighting Americans' attention to his accomplishments rather than his birthday (pp. 876-77, 910-11). For example, in Figure 3, Philadelphians' July 4 song deploring that "the slaves of a tyrant his birthday revere" is answered by the next two clippings' honoring of Washington's wartime contributions to the nation through lyrics written in the 1780s and 1790s. ${ }^{77}$ Tracing a shift in American commemorative rituals and music away from monarchical models followed Jefferson's prediction in 1799 of what Benjamin Rush called a "resuscitation of its republic Spirit."78 That spirit was reflected not simply in elections but also in rituals and language. Jefferson's juxtaposition of British monarchical ritual expression and American republican expression illustrates the epideictic use of scrapbooks to spotlight aspects of events for praise or condemnation. ${ }^{79}$

In preserving and organizing song lyrics marking births, elections, inaugurations, and retirement, Jefferson crafted a larger statement about American adherence to republican values following earlier pursuit of monarchical rites and titles, such as "His Excellency" and "His Highness the President" during Washington's presidency. ${ }^{80}$ As Watson has noted, antebellum collections could reflect "not only the self in relation to printed texts. . but also the self in relation to other people and their reading." ${ }^{81}$ More specifically, men used scrapbooks to situate themselves in a large collective, commemorate collective achievement, and "celebrate milestones in a collective endeavor." $\$ 2$ In Jefferson's case, this entailed documenting progress of the larger republican constituency to which he referred in his correspondence. ${ }^{83}$ Rather than simply recording public approval of his own performance, which McDonald has stressed, these political songs clarify how Jefferson's leadership, service, and assessment of his contributions were bound up with the development of a large republican public as expressed in music and commemorative ritual.

\footnotetext{
${ }^{74}$ Albany Register, August 18, 1807, 2; William Ray, Horrors of Slavery: or, the American Tars in Tripoli (Troy, NY: Oliver Lyon, 1808), 292-93. The clipping itself was taken from Pittsfield Sun, August 29, 1807, 4.

75 "Thomas Jefferson's Explanations of the Three Volumes Bound in Marbled Paper (the so-called 'Anas'), 4 February 1818," Founders Online, National Archives, https://founders.archives.gov/documents/Jefferson/03-12-02-0343-0002; Burstein, Inner Jefferson, 209.

${ }^{76}$ Merry Ellen Scofield, "The Fatigues of His Table: The Politics of Presidential Dining during the Jefferson Administration," Journal of the Early Republic 26, no. 3 (Fall 2006): 461, https://doi.org/10.1353/jer.2006.0055.

${ }^{77}$ Gross, Thomas Jefferson's Scrapbooks, 14-15, 32.

78 “To Thomas Jefferson from Benjamin Rush, 12 March 1801," Founders Online, National Archives, https://founders.archives.gov/documents/Jefferson/01-33-02-0221.

${ }^{79}$ Katriel and Farrell, "Scrapbooks," 4.

${ }^{80}$ Lohman, Hail Columbia!, 54.

${ }^{81}$ Watson, "Shared Reading," 107.

${ }^{82}$ Gilger, "Otherwise Lost or Forgotten," 112; Ott, "Between Person and Profession," 31.

83 "From Thomas Jefferson to Martha Jefferson Randolph, 6 July 1806," Founders Online, National Archives, https://founders.archives.gov/documents/Jefferson/99-01-02-3969.
} 


\section{Struggling}

Jefferson also preserved records of the nation's international struggles during his presidency. He clipped Americans' responses to international challenges, setbacks, defeats, and concerns that impacted individuals and the nation. These include the Tripolitan War, acts of British naval aggression, and the protracted and economically devastating embargo against international trade during his second term.

Verses throughout the political song grouping recount the plight of American seamen held captive in Tripoli and the military efforts preceding their release at the end of the Tripolitan War in $1805 .{ }^{84}$ The Bashaw of Tripoli had declared war in 1801 after the United States did not agree to pay tribute money to protect American merchant vessels from piracy. In one of the American naval squadrons successively sent to the Mediterranean, the USS Philadelphia ran aground in Tripoli harbor in 1803, and approximately 300 American seamen were held captive in Tripoli in horrid conditions and assigned to hard labor. In contrast with the later portrayal of the conflict as an American triumph, ${ }^{85}$ Jefferson preserved accounts of human suffering and death from the seamen's captivity and the ill-fated use of a combustible fireship to destroy the captive frigate, along with postwar accounts. Jefferson's record acknowledged suffering and failure glossed over in contemporaneous Republican partisan discourse that incessantly repeated peace as a hallmark of Republican leadership. ${ }^{86}$

A noteworthy clipping preserving the seamen's fate is "Ode to Liberty," written by one of the captive seamen, William Ray (1771-1827) (p. 891, Figure 4). The seaman's verses circulated in summer 1805 with a letter in which naval surgeon Jonathan Cowdery recounted his treatment, the seamen's labor and hunger, the officers' confinement, access to provisions, and the Bashaw's expectations of American payment for peace and the men's release. ${ }^{87}$ When Ray subsequently published his song, he noted that the prisoners sang it on Christmas evening and indicated the tune as Charles Dibdin's "Madam You Know My Trade Is War." 88 Jefferson's preservation of this clipping not only illustrates an interest in documenting the war as an international challenge, but also reflects his evaluation of Ray's writing. After Jefferson and Ray corresponded from 1807, Jefferson asked his successor James Madison to help Ray, explaining, "I think he has too much genius for the low station in which he was in the navy," and asking Madison "to place him in your recollection, if any occasion should arise wherein such a man can be useful in the navy or elsewhere." ${ }^{\prime 9}$ Jefferson's assessment of Ray's writing sustained an emphasis on the quality of verse seen in his correspondence with his granddaughters. ${ }^{90}$

\footnotetext{
${ }^{84}$ This conflict is explicitly or implicitly referenced in clippings on pages 875, 885-86, 891, 892, 894, 898, 901-2, 925-26, 939-41.

${ }^{85}$ McDonald, Confounding Father, 174.

${ }^{86}$ Lohman, Hail Columbia!, 165-66, 171-74.

87 "Interesting Letter from Tripoli," Boston Gazette, August 29, 1805, 1; “Ode to Liberty," Boston Gazette, August $29,1805,4$.

${ }^{88}$ Ray, Horrors of Slavery, 149-51; William Ray, Poems, on Various Subjects, Religious, Moral, Sentimental and Humorous (Auburn, NY: U. F. Doubleday, 1821), 95-97.

89 “To Thomas Jefferson from William Ray, 5 February 1807," Founders Online, National Archives, https://founders.archives.gov/documents/Jefferson/99-01-02-5019; “To Thomas Jefferson from William Ray, 22 November 1808," Founders Online, National Archives, https://founders.archives.gov/documents/Jefferson/99-01-02-9138; "From Thomas Jefferson to William Ray, 14 December 1808," Founders Online, National Archives, https://founders.archives.gov/documents/Jefferson/99-01-02-9317; "William Ray to Thomas Jefferson, 7 March 1809," Founders Online, National Archives, https://founders.archives.gov/documents/Jefferson/03-01-02-0020; "Thomas Jefferson to James Madison, 24 March 1809," Founders Online, National Archives, https://founders.archives.gov/documents/Jefferson/03-01-02-0064.

90 "From Thomas Jefferson to Ellen Wayles Randolph Coolidge, 4 March 1805," Founders Online, National Archives, https://founders.archives.gov/documents/Jefferson/99-01-02-1298.
} 


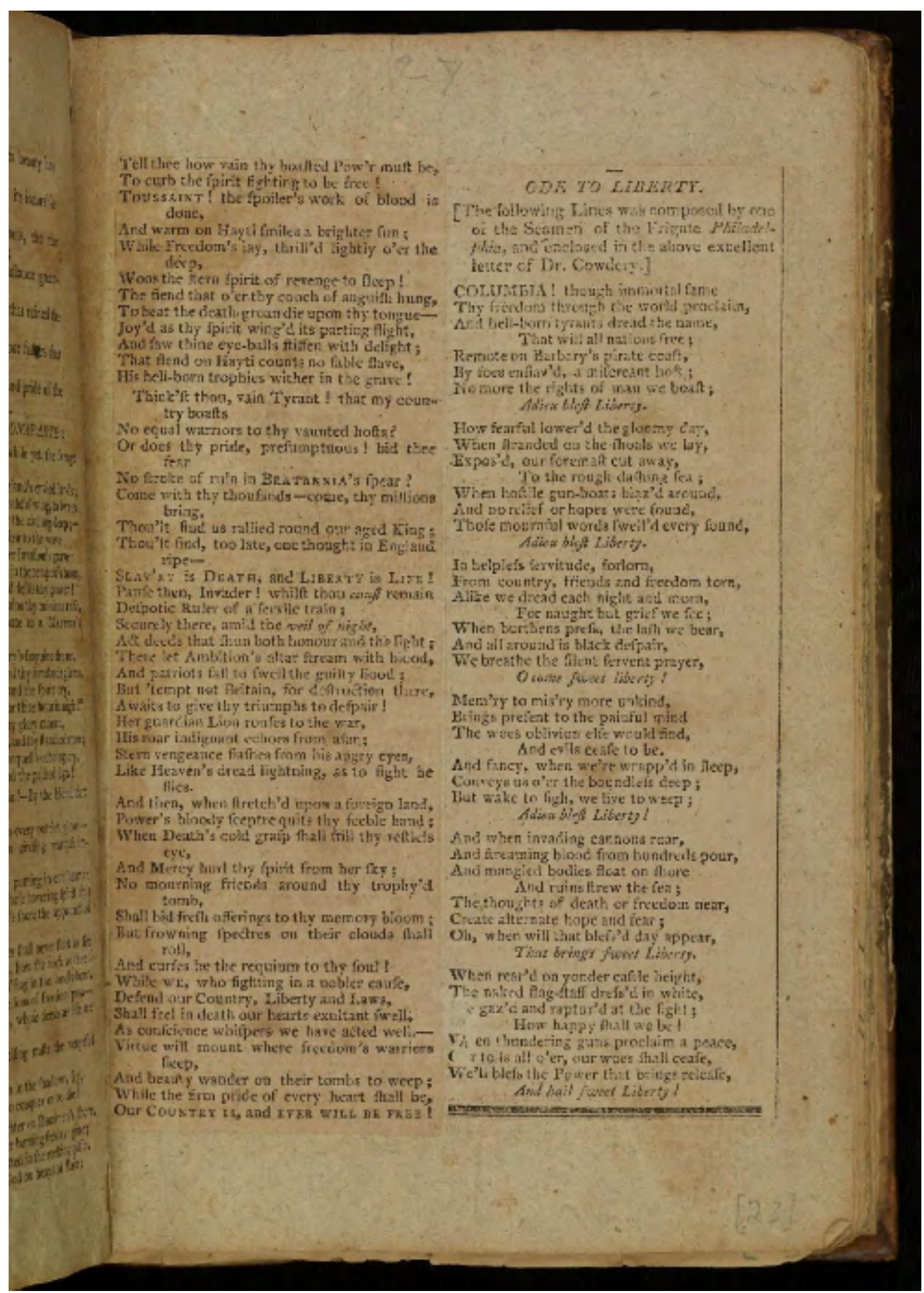

Figure 4: William Ray's "Ode to Liberty" preserved in the scrapbook alongside verses reprinted in the United States from a London newspaper. University of Virginia Library. 
Jefferson's attention to his correspondent Ray's verse extended into other clippings, including those that preserved Americans' responses to British naval aggression and impressment. Jefferson clipped Ray's "War, or a Prospect of It, From recent instances of British Outrage" (p. 904). Ray wrote it July 20, 1807, after an audacious British attack on an American naval vessel off the Virginia coast. ${ }^{11}$ In pursuit of deserters, the HMS Leopard fired on the USS Chesapeake and took four men from the American frigate. With this attack, British impressment escalated from American merchant vessels to an American naval vessel. The incident extended previous outrage prompted when seaman John Pierce was shot and killed by cannon fire from the HMS Leander on April 25, 1806, off Sandy Hook, an incident also preserved in a clipping (pp. 873-75). Jefferson's interest in Republican Americans' anger over British impressment extended to clippings of John DeWolf's (1786-1862) "Song” (pp. 938-39, Figure 5), which circulated in July 1808. ${ }^{92}$ Part of a Bristol, Rhode Island, family enriched through the slave trade and distilling rum, DeWolf went on to become a professor of chemistry at Brown University. His lyrics were set to music in 1808, printed as a broadside, and performed by American prisoners to commemorate July 4 on board a British prison ship during the War of 1812, a performance that brought many prisoners to tears. ${ }^{93}$

By these verses' circulation in 1808, Jefferson had long been desiring retirement and reported "beginning to retire from the paper reading." "Nevertheless, he preserved in the political song grouping at least fifty-seven items printed in 1807 and 1808. These contain twelve items dedicated to the embargo (pp. 913-21), which prohibited international trade in response to impressment and growing challenges to American neutrality during the Napoleonic Wars. The clippings include humorous songs about the embargo, among them several parodies from a witty exchange between Republican and Federalist songwriters who took opposing positions on the legislation. ${ }^{95}$ Sustaining this attention to the nation's problematic relationship with Britain and France, Jefferson next positioned seven widely reprinted submissions to an 1808 national contest calling for martial songs and tunes amid continued concern with British aggression (pp. 921-28). ${ }^{96}$

\footnotetext{
${ }^{91}$ Ray, Horrors of Slavery, 288-89.

92 “Song," Eastern Argus (Portland, ME), July 28, 1808, 4; “Selected Poetry,” Essex Register (Salem, MA), August 6, $1808,1$.

93 "The Impressment of an American Sailor Boy, Sung on Board the British Prison Ship Crown Prince, the Fourth of July, 1814 by a Number of the American Prisoners," New York Historical Society, 1814; Francis Abell, Prisoners of War in Britain 1756 to 1815: A Record of Their Lives, Their Romance and Their Sufferings (London: Oxford University Press, 1914 ), 89.

94 "From Thomas Jefferson to James Cheetham, 6 November 1807," Founders Online, National Archives, https://founders.archives.gov/documents/Jefferson/99-01-02-6715.

${ }^{95}$ Lohman, "More Truth than Poetry," 48-51. The poetry volume also preserves items critical of the embargo and its devastating impacts on Americans (pp. 680-82, 688-89).

96 “National Airs," L'Oracle and Daily Advertiser (New York), April 15, 1808, 2; Lohman, Hail Columbia!, $208-11$.
} 


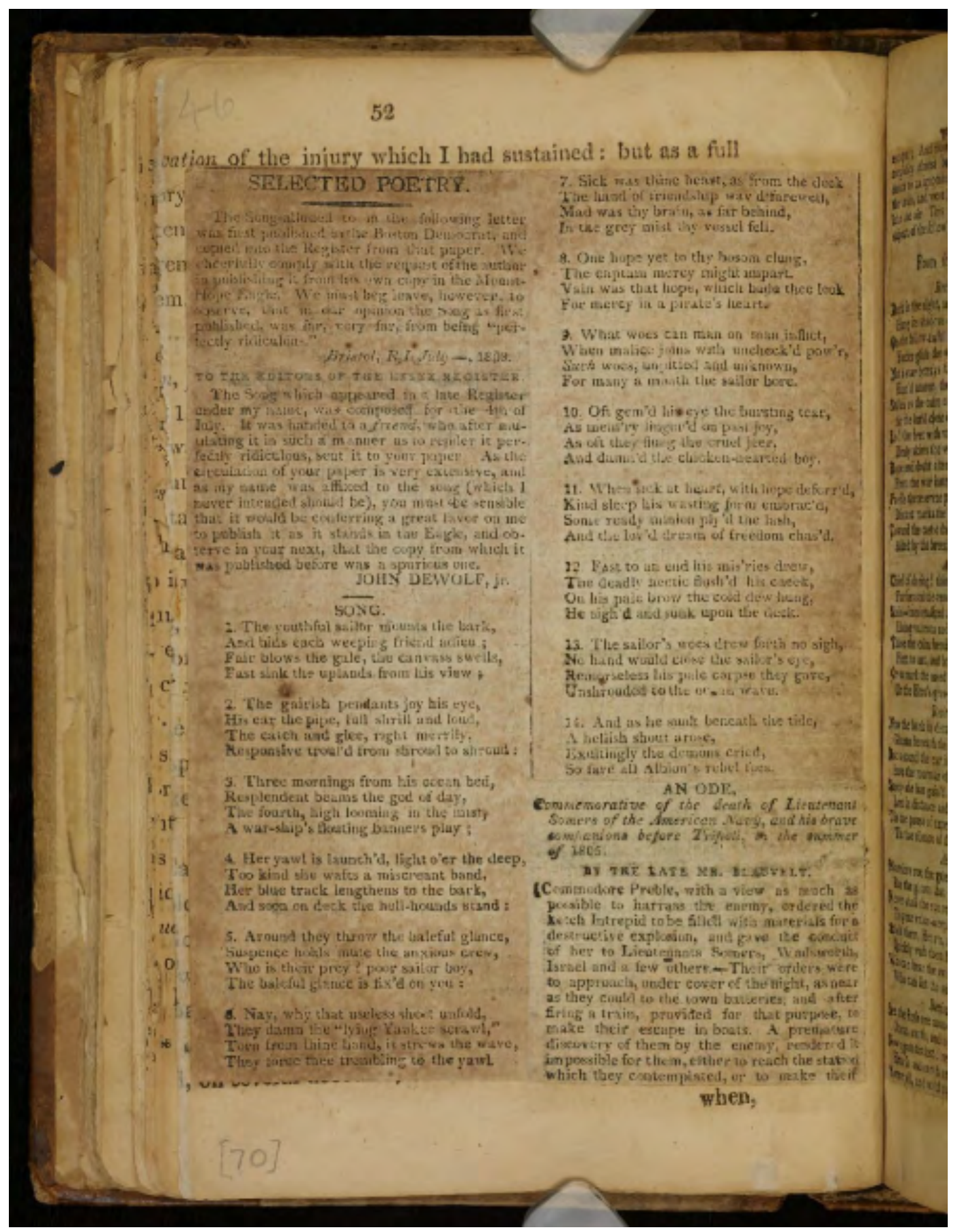

Figure 5: John DeWolf's "Song” bemoaning British impressment was pasted alongside one of the many clippings recounting human suffering, death, and conflict during the Tripolitan War. University of Virginia Library.

Jefferson preserved varied responses to challenges to American neutrality as the Napoleonic Wars dragged on. Explaining the embargo, Jefferson stressed that avoiding entanglement in "the system of European interests" and sustaining peace could ensure both freedom from national debt and an economic position sufficient for any war. ${ }^{97}$ Both song contest submissions and songs on the embargo advocated

\footnotetext{
97 "From Thomas Jefferson to Obadiah B. Brown, 17 October 1808," Founders Online, National Archives, https://founders.archives.gov/documents/Jefferson/99-01-02-8877; "From Thomas Jefferson to James Monroe, 28 January 1809," Founders Online, National Archives, https://founders.archives.gov/documents/Jefferson/99-01-02-9666.
} 
positions ranging from peace to calls to arms, supported by images of grieving parents and frightened children, as would recur in music written in response to later conflicts like World War I. ${ }^{98}$ During his final months in office, Jefferson presented Congress a choice between embargo and war and increasingly referred to the prospect of war, which he projected for May or June $1809 .{ }^{99}$ Read in this context, the final clipping of the political grouping gains additional significance. As an 1808 reprinting of an 1802 song proclaiming a commitment to American arms, preservation of the clipping at first seems to contradict the position taken by many Republicans in defending the embargo. ${ }^{100}$ Yet when read in conjunction with Jefferson's correspondence, the song's touting of American military prowess mirrors his increasing acknowledgment of the prospect of war in his correspondence in 1808 and 1809.

\section{Timing}

While parts of Jefferson's scrapbooks can be read as a record of his concern with the public's assessment of his performance, ${ }^{101}$ this reading obscures temporal aspects of the volumes. In Laird's volume, these temporal aspects include how Americans used musical commemoration of past events to make sense of the present and future. They also include how Jefferson fused consideration of past and current accomplishments with an awareness of posterity to address personal struggles while in office.

While commemorating past events, songs that Americans wrote for July 4 and that Jefferson preserved also addressed contemporary developments. As Yang has stressed, musical commemoration can be "a way of using the past to serve the present." ${ }^{102}$ Americans' use of the past to understand and urge action in the present in song can be seen in Figure 3 (p. 876). The right-hand clipping cut from the Epitome of the World (Bennington, Vermont) was a reprinting of a song, "From the Aurora," a leading Philadelphia Republican newspaper. ${ }^{103}$ The song was written for the July 4 anniversary and sung by a group of Republicans who had organized to prevent Thomas McKean's reelection as governor of Pennsylvania in $1805 .{ }^{104}$ The second verse vowed to remember the past, specifically the revolutionary "heroes and sages," the enemy they defeated, and the contest they fought. Supported by specific parallels to revolutionary era actions, such as the Battles of Saratoga, these historical references fueled the third verse's vows to continue fighting British aggression.

\footnotetext{
${ }^{98}$ Christina Gier, "War, Anxiety, and Hope in American Sheet Music, 1914-1917," Music and Politics 7, no. 1 (Winter 2013), 5-6, 12, https://doi.org/10.3998/mp.9460447.0007.102;

99 "From Thomas Jefferson to Michael Leib, 23 June 1808," Founders Online, National Archives, https://founders.archives.gov/documents/Jefferson/99-01-02-8204; "From Thomas Jefferson to Charles Pinckney, 8 November 1808," Founders Online, National Archives, https://founders.archives.gov/documents/Jefferson/99-01-02-9059; "Notes on a Cabinet Meeting, 1 December 1808," Founders Online, National Archives, https://founders.archives.gov/documents/Jefferson/99-01-02-9209; "From Thomas Jefferson to Charles Lewis Bankhead, 19 January 1809," Founders Online, National Archives, https://founders.archives.gov/documents/Jefferson/99-01-02-9581; "From Thomas Jefferson to James Monroe, 28 January 1809," Founders Online, National Archives, https://founders.archives.gov/documents/Jefferson/99-01-02-9666; "From Thomas Jefferson to Thomas Mann Randolph, 31 January 1809," Founders Online, National Archives, https://founders.archives.gov/documents/Jefferson/99-01-02-9687; "From Thomas Jefferson to Thomas Mann Randolph, 7 February 1809," Founders Online, National Archives, https://founders.archives.gov/documents/Jefferson/99-01-02-9735.

100 "Poetry," American Mercury (Hartford, CT), September 15, 1808, 4.

${ }^{101}$ McDonald, Confounding Father, 128, 130, 235.

${ }^{102}$ Yang, "Power, Politics, and Musical Commemoration," 1-2; Lohman, "Singing 'Past, Present and Future," $192-223$.

103 "Song," Epitome of the World (Bennington, VT), August 3, 1807, 4.

${ }^{104}$ Albrecht Koschnik, "Let a Common Interest Bind Us Together": Associations, Partisanship, and Culture in Philadelphia, 1775-1840 (Charlottesville: University of Virginia Press, 2007), 67; "From the Aurora," Kline’s Carlisle Weekly Gazette, April 5, 1805, 2.
} 


\section{Music and Politics Winter 2022}

When facing "the old haughty foe," the song maintained, "we are still, / Such men as they found us at old Bunker's hill."

As we can nuance Americans' temporal orientation in their musical commemorations, we can also nuance Jefferson's temporal orientation to commemorative scrapbooks like Laird's volume. McDonald has concluded that Jefferson was the scrapbooks' "only immediate audience." ${ }^{105}$ We can consider more specifically how Jefferson's current or future self may have composed that audience, guided by Katriel and Farrell's observation that scrapbooks serve as commemorative texts "with the maker's projected 'self serving as the primary future audience." 106 While modern scrapbookers enable their "future reflective contemplation" with emphasis on pride and satisfaction when later reviewing past experiences, Jefferson's writings suggest a broader range of possible future contemplative uses, including using the scrapbook as an object to support critical self-assessment and to reconsider, as he had in 1800, "whether my country is the better for my having lived at all?" 107 Jefferson was also the scrapbooks' audience while planning and making them. As Burstein noted that Jefferson "thought it demeaning to voice too obvious a concern with public approbation," did constructing the scrapbooks provide an outlet for such a concern in private? ${ }^{108}$ Intriguingly, when addressing John Adams's inquiry about a reported scrapbook of "libels" against Jefferson, he acknowledged cutting newspaper poetry for his grandchildren and annually having pamphlets bound, but avoided acknowledging that he cut and had bound newspaper clippings of any kind for himself. ${ }^{109}$

Katriel and Farrell note of scrapbooking that "the act of saving is both retrospectively and prospectively oriented." ${ }^{110}$ Underscoring scrapbooks' prospective orientation, Jefferson's writings reveal his contemplation of future assessments and reputations. ${ }^{111}$ Concerned about Federalists' accounts of American political history, Jefferson wrote of Republicans in 1823, "We have been too careless of our future reputation." 112 Concern with his post-presidential reputation surfaced in his first inaugural address. He acknowledged of the presidency, "I have learnt to expect that it will rarely fall to the lot of imperfect man to retire from this station with the reputation \& the favor which bring him into it." 113 According to his correspondence, Jefferson's concern with his future reputation shaped his decision to stand for a second presidential term, and it informed his specification of his epitaph. ${ }^{114}$ Writing to his daughter Martha, he lamented that "the unlimited calumnies of the federalists have obliged me to put myself on the trial of my country by standing another election. I have no fear as to their verdict; and that being secured for posterity, no considerations

\footnotetext{
${ }^{105}$ McDonald, Confounding Father, 129; Garvey, Writing with Scissors, 20; Katriel and Farrell, "Scrapbooks,” 6-8.

${ }^{106}$ Katriel and Farrell, "Scrapbooks," 8.

${ }^{107}$ Katriel and Farrell, "Scrapbooks," 6; "Summary of Public Service, [after 2 September 1800]," Founders Online, National Archives, https://founders.archives.gov/documents/Jefferson/01-32-02-0080

${ }^{108}$ Burstein, Inner Jefferson, 173-74.

109 "To Thomas Jefferson from John Adams, 10 February 1823," Founders Online, National Archives, https://founders.archives.gov/documents/Jefferson/98-01-02-3319; "From Thomas Jefferson to John Adams, 25 February 1823," Founders Online, National Archives, https://founders.archives.gov/documents/Jefferson/98-01-02-3357; McDonald, Confounding Father, 239-42.

${ }^{110}$ Katriel and Farrell, "Scrapbooks," 7.

${ }^{111}$ Burstein, Inner Jefferson, 173; McDonald, Confounding Father, 62, 84; Robert M. S. McDonald, "Thomas Jefferson and Historical Self-Construction: The Earth Belongs to the Living?” The Historian, 61, no. 2 (Winter 1999): 290, https://doi.org/10.1111/i.1540-6563.1999.tb01027.x.

112 "From Thomas Jefferson to William Johnson, 4 March 1823," Founders Online, National Archives, https://founders.archives.gov/documents/Jefferson/98-01-02-3373; McDonald, “Thomas Jefferson," 291-93.

113 "I. First Draft, [before 4 March 1801]," Founders Online, National Archives, https://founders.archives.gov/documents/Jefferson/01-33-02-0116-0002.

${ }^{114}$ McDonald, Confounding Father, 217-19.
} 
will induce me to continue beyond the term to which it will extend." 115 Was constructing the scrapbook's political song grouping an effort to capture the public's assessment in assurance that his future reputation was secured? Other scrapbook portions certainly did so, such as a Republican article titled "Mr. Jefferson's Retirement," which asserted that "his character has now attained a maturity of virtue, which may defy all the calumnies of his enemies and must command the veneration of posterity" (p. 545). Jefferson complemented others' assessments with retrospective and prospective self-assessments. He questioned his contributions and compared his efforts with others. In 1807 he confessed, "I am tired of an office where I can do no more good than many others who would be glad to be employed in it." He continued, "my only consolation is in the belief that my fellow citizens at large give me credit for good intentions."

Such statements suggest that public approbation and appreciation helped him continue in service as he increasingly yearned to return to retirement and proximity to his family and became frustrated with aspects of the job. ${ }^{117}$ His correspondence with his granddaughters to shape their collections-at times including clippings of verse he pasted into his own collection of sentimental verse-illustrates how nineteenth-century collections could sustain familial relationships and help their creators "remain connected with loved ones at home" as well as their earlier "identities and mindsets." 118 While public approbation was outweighed at the start of his second term by grief over one daughter's death and despair over the ill health of another, Jefferson later called his "republican fellow citizens"” approbation "the dearest reward I can carry into retirement." 119 He anticipated his own physical and mental decline, and by January 1808, he reported "panting" after retirement. ${ }^{120}$ Working on the scrapbooks, including Laird's volume, may have offered a therapeutic way of dealing with a too-distant retirement and the frustrations of a job that he described as "drudgery" and unpaid labor. ${ }^{121}$

\footnotetext{
115 "From Thomas Jefferson to Martha Jefferson Randolph, 6 November 1804," Founders Online, National Archives, https://founders.archives.gov/documents/Jefferson/01-44-02-0584; "From Thomas Jefferson to Elbridge Gerry, 3 March 1804," Founders Online, National Archives, https://founders.archives.gov/documents/Jefferson/01-42-02-0509.

116 "Summary of Public Service, [after 2 September 1800]," Founders Online, National Archives, https://founders.archives.gov/documents/Jefferson/01-32-02-0080; "From Thomas Jefferson to John Dickinson, 13 January 1807," Founders Online, National Archives, https://founders.archives.gov/documents/Jefferson/99-01-02-4861.

117 "From Thomas Jefferson to Martha Jefferson Randolph, 6 July 1806," Founders Online, National Archives, https://founders.archives.gov/documents/Jefferson/99-01-02-3969.

${ }^{118}$ Marie Kimball, “A Playmate of Thomas Jefferson," The North American Review 213, no. 783 (February 1921), 150; “To Thomas Jefferson from Ellen Wayles Randolph Coolidge, 20 July 1805," Founders Online, National Archives, https://founders.archives.gov/documents/Jefferson/99-01-02-2112; Watson, "Shared Reading," 103; Rusk, "Collecting the Confederacy," 267.

119 "From Thomas Jefferson to Adrienne-Catherine de Noailles, comtesse de Tessé, 10 March 1805," Founders Online, National Archives, https://founders.archives.gov/documents/Jefferson/99-01-02-1355; "From Thomas Jefferson to Michael Leib, 12 August 1805," Founders Online, National Archives, https://founders.archives.gov/documents/Jefferson/99-01-022232; "From Thomas Jefferson to Andrew Ellicott, 1 November 1806," Founders Online, National Archives, https://founders.archives.gov/documents/Jefferson/99-01-02-4489; "From Thomas Jefferson to John Dickinson, 13 January 1807," Founders Online, National Archives, https://founders.archives.gov/documents/Jefferson/99-01-02-4861; "From Thomas Jefferson to Michael Leib, 23 June 1808,” Founders Online, National Archives, https://founders.archives.gov/documents/Jefferson/99-01-02-8204.

120 "From Thomas Jefferson to William Short, 19 May 1807," Founders Online, National Archives, https://founders.archives.gov/documents/Jefferson/99-01-02-5599; "From Thomas Jefferson to Joel Barlow, 24 January 1808," Founders Online, National Archives, https://founders.archives.gov/documents/Jefferson/99-01-02-7262.

121 "From Thomas Jefferson to Elbridge Gerry, 3 March 1804," Founders Online, National Archives, https://founders.archives.gov/documents/Jefferson/01-42-02-0509; "From Thomas Jefferson to Martha Jefferson Randolph, 6 November 1804," Founders Online, National Archives, https://founders.archives.gov/documents/Jefferson/99-01-02-0599; "From Thomas Jefferson to James Monroe, 28 January 1809," Founders Online, National Archives, https://founders.archives.gov/documents/Jefferson/99-01-02-9666; "From Thomas Jefferson to C. P. de Lasteyrie, 15 July 1808," Founders Online, National Archives, https://founders.archives.gov/documents/Jefferson/99-01-02-8329.
} 
This interpretation is supported by several observations from dating clippings in the political song grouping and the paper on which they were pasted. Using these observations, we can infer when Jefferson worked on the scrapbook. The process of planning and constructing the scrapbook would have entailed reading, clipping, possibly grouping related loose clippings, pasting clippings onto waste paper and fixing some into successive relationships, annotating intended locations of clippings on waste paper, and constructing pages of waste paper into groupings for binding. ${ }^{122}$ Not only were nearly all items following the series of embargo songs printed in 1808 , but at least forty clippings, or $41 \%$ of the datable clippings, were printed in 1808. The second and third largest datable subsets can be traced to 1807 and 1805, respectively (see Table 2), with a smaller number datable to 1806, when his daughter and grandchildren resided with him for nearly half the year. ${ }^{123}$ In total, roughly half or more of the clippings were printed in 1807 and 1808. Moreover, the final third of the waste paper was printed in 1807 as the book A Vindication of Mrs. Lee's Conduct Towards the Gordons (pp. 919-43). Some clippings were printed later than the songs first appeared. Important examples are the first clipping, which was printed in 1805, and the last clipping, which was printed in 1808, ${ }^{124}$ despite the song lyrics first appearing in 1801 and 1802, respectively. All these considerations suggest that the bulk of Jefferson's attention to the planning and construction of this portion of the scrapbook occurred in his second term, and specifically during 1807 and 1808, even if he conceptualized and began selecting clippings for the collection earlier.

\begin{tabular}{|l|l|}
\hline Year or Decade & Number of Items Printed \\
\hline 1780 s & 2 \\
\hline 1790 s & 2 \\
\hline 1800 & 1 \\
\hline 1801 & 3 \\
\hline 1802 & 6 \\
\hline 1803 & 2 \\
\hline 1804 & 4 \\
\hline 1805 & 12 \\
\hline 1806 & 9 \\
\hline 1807 & 17 \\
\hline 1808 & 40 \\
\hline Not yet determined & 17 \\
\hline
\end{tabular}

Table 2: Clipped items in the political song group, counted by year or decade of printing.

Jefferson repeatedly lamented having been forced, through "a sense of duty," into high-profile political leadership by the revolutionary times in which he was born, despite his "great and constant aversion" to

\footnotetext{
${ }^{122}$ McDonald, Confounding Father, 296.

${ }^{123}$ Scofield, "The Fatigues of His Table," 463.

124 “Jefferson and Liberty," Weekly Eastern Argus (Portland, ME), March 8, 1805, 3.
} 
political life. ${ }^{125}$ Was making the scrapbooks, and especially the political song grouping, a way of processing political work, about which he had mixed feelings, in a studious mode more aligned with his preferences? It would have been consistent with the purposeful nature of his other collections, such as preserving the notes of "Anas" to set a historical record straight and cutting biblical translations to process and compile the morals he found in the New Testament.

\section{Conclusion}

The political songs in the scrapbook volume record a multifaceted commemoration of a presidency that sits at the intersection of personal commemoration by the scrapbook's creator and public commemoration at the local and national levels. Commemorating a major period in Jefferson's life, the collection tracks domestic political developments among a large republican constituency and betrays concern with international struggles, including those that developed into the greatest challenges of his second term. Examining the volume adds nuanced readings, attributions, and evidence to previous accounts of Jefferson's presidential era scrapbooks, complements recent research on early American music and politics, and expands our understanding of the varied early American collections that preserve music. Considering the collection's temporality nuances our understanding of its relationship to Jefferson's concern with self-assessment, public assessment, and reputation. Reading the political song grouping in conjunction with Jefferson's correspondence highlights varied connections between music and politics in practices of commemoration and provides further support for the scrapbooks' attribution to Jefferson.

Commenting on Jefferson's autobiographical projects, Crow concluded that “[i]n various projects of representing his life to himself, he was playing a kind of game with the connections between selfunderstanding and political life, a game that prepared and constructed not only a self for politics, but a politics of self-construction." ${ }^{26}$ The political song grouping may be interpreted as an extension of this practice. While political verse like that preserved in the scrapbook has often been dismissed on aesthetic grounds, such lyrics had enough value to construct a measure of self, a measure of republican progress, and a record of national struggles during protracted international conflict. Moreover, to the extent that this portion of the scrapbook is "a metonymic assemblage of one's social self," 127 this collection of political songs shows how Jefferson's leadership, service, and assessment of his contributions were bound up not only with his family, correspondents, and acquaintances, but also with the development of a large republican public as expressed in music and commemorative ritual.

\section{Bibliography}

\section{Abell, Francis. Prisoners of War in Britain 1756 to 1815: A Record of Their Lives, Their Romance and Their Sufferings. London: Oxford University Press, 1914.}

\footnotetext{
125 "From Thomas Jefferson to George Clinton, 31 December 1803," Founders Online, National Archives, https://founders.archives.gov/documents/Jefferson/01-42-02-0195; "From Thomas Jefferson to David Bailie Warden, 25 February 1809," Founders Online, National Archives, https://founders.archives.gov/documents/Jefferson/99-01-02-9902; "From Thomas Jefferson to C. P. de Lasteyrie, 15 July 1808," Founders Online, National Archives, https://founders.archives.gov/documents/Jefferson/99-01-02-8329.

${ }^{126}$ Crow, "History, Politics, and the Self," 477.

${ }^{127}$ Katriel and Farrell, "Scrapbooks," 5.
} 
Adams, Dickinson W. Jefferson's Extracts from the Gospels: The Philosophy of Jesus and The Life and Morals of Jesus. Princeton, NJ: Princeton University Press, 2014.

Anderson, Douglas. "Subterraneous Virginia: The Ethical Poetics of Thomas Jefferson.” EighteenthCentury Studies 33, no. 2 (Winter 2000): 233-49. https://doi.org/10.1353/ecs.2000.0003.

Bailey, Candace. "Binder's Volumes as Musical Commonplace Books: The Transmission of Cultural Codes in the Antebellum South." Journal of the Society for American Music 10, no. 4 (November 2016): 446-69. https://doi.org/10.1017/S1752196316000353.

Bailey, Candace. Unbinding Gentility: Women Making Music in the Nineteenth-Century South. Urbana: University of Illinois Press, 2021. https://doi.org/10.5406/j.ctv1k03s8m.

Baker, Malcolm. "Public Fame or Private Remembrance? The Portrait Bust and Modes of Commemoration in Eighteenth-Century England." In Memory \& Oblivion, edited by Wessel Reinink and Jeroen Stumpel, 527-35. Dordrecht: Springer, 1999. https://doi.org/10.1007/978-94$\underline{011-4006-5 \quad 60 .}$.

Beiner, Guy. "Negotiations of Memory: Rethinking 1798 Commemoration." The Irish Review 26 (Autumn 2000): 60-70. https://doi.org/10.2307/29735992.

Browne, Stephen Howard. “The Circle of Our Felicities': Thomas Jefferson's First Inaugural Address and the Rhetoric of Nationhood." Rhetoric and Public Affairs 5, no. 3 (Fall 2002): 409-38. https://doi.org/10.1353/rap.2002.0050.

Burke, Victoria E. "Recent Studies in Commonplace Books." English Literary Renaissance 43, no. 1 (Winter 2013): 153-77. https://doi.org/10.1111/1475-6757.12005.

Burstein, Andrew. The Inner Jefferson: Portrait of a Grieving Optimist. Charlottesville: University of Virginia Press, 1996.

Coleman, Billy. Harnessing Harmony: Music, Power, and Politics in the United States, 1788-1865. Chapel Hill: University of North Carolina Press, 2020. https://doi.org/10.5149/northcarolina/9781469658872.001.0001.

Cripe, Helen. Thomas Jefferson and Music. Charlottesville: University of Virginia Press, 1974.

Crow, Matthew E. "History, Politics, and the Self: Jefferson's 'Anas' and Autobiography." In $A$ Companion to Thomas Jefferson, edited by Francis D. Cogliano, 477-90. Malden, MA: WileyBlackwell, 2012. https://doi.org/10.1002/9781444344639.ch29.

Davis, Richard Beale. "Jefferson as Collector of Virginiana." Studies in Bibliography 14 (1961): 117-44.

Fauser, Annegret, and Michael A. Figueroa, eds. Performing Commemoration: Musical Reenactment and the Politics of Trauma. Ann Arbor: University of Michigan Press, 2020. https://doi.org/10.3998/mpub.11560559.

Ferling, John. Adams vs. Jefferson: The Tumultuous Election of 1800. New York: Oxford University Press, 2004.

Forrest, Alan. Napoleon's Men: The Soldiers of Revolution and Empire. London: Hambledon Continuum, 2006.

Garvey, Ellen Gruber. Writing with Scissors: American Scrapbooks from the Civil War to the Harlem Renaissance. New York: Oxford University Press, 2012. https://doi.org/10.1093/acprof:oso/9780195390346.001.0001.

Gier, Christina. "War, Anxiety, and Hope in American Sheet Music, 1914-1917." Music and Politics 7, no. 1 (Winter 2013). https://doi.org/10.3998/mp.9460447.0007.102. 
Gilger, Kristin. "Otherwise Lost or Forgotten: Collecting Black History in L. S. Alexander Gumby's 'Negroana' Scrapbooks.” African American Review 48, no. 1/2 (Spring/Summer 2015): 111-26. https://doi.org/10.1353/afa.2015.0004.

Goertzen, Chris. "Philander Seward's 'Musical Deposit' and the History of American Instrumental Folk Music." Ethnomusicology 26, no. 1 (January 1982): 1-10. https://doi.org/10.2307/851397.

Goodman, Glenda. Cultivated by Hand: Amateur Musicians in the Early American Republic. New York: Oxford University Press, 2020. https://doi.org/10.1093/oso/9780190884901.001.0001.

Goodman, Glenda. "Transatlantic Contrafacta, Musical Formats, and the Creation of Political Culture in Revolutionary America." Journal of the Society for American Music 11, no. 4 (November 2017): 392-419. https://doi.org/10.1017/S1752196317000359.

Gray, Myron. "A Partisan National Song: The Politics of 'Hail Columbia' Reconsidered." Music and Politics 11, no. 2 (Summer 2017). https://doi.org/10.3998/mp.9460447.0011.201.

Gross, Jonathan, ed. Thomas Jefferson's Scrapbooks: Poems of Nation, Family, and Romantic Love Collected by America's Third President. Hanover, NH: Steerforth Press, 2006.

Hayes, Kevin J. "The Libraries of Thomas Jefferson." In A Companion to Thomas Jefferson, edited by Francis D. Cogliano, 333-48. Malden, MA: Wiley-Blackwell, 2012. https://doi.org/10.1002/9781444344639.ch21.

Henkin, David. City Reading: Written Words and Public Spaces in Antebellum New York. New York: Columbia University Press, 1998.

Hunt, Leigh Ina. "Victorian Passion to Modern Phenomenon: A Literary and Rhetorical Analysis of Two Hundred Years of Scrapbooks and Scrapbook Making." PhD diss., The University of Texas at Austin, 2006.

"The Impressment of an American Sailor Boy, Sung on Board the British Prison Ship Crown Prince, the Fourth of July, 1814 by a Number of the American Prisoners." New York Historical Society, 1814.

James, Felicity, and Rebecca Shuttleworth. "Susanna Watts and Elizabeth Heyrick: Collaborative Campaigning in the Midlands, 1820-34.” In Women's Literary Networks and Romanticism: "A Tribe of Authoresses," edited by Andrew O. Winckles and Angela Rehbein, 47-72. Liverpool: Liverpool University Press, 2017. https://doi.org/10.2307/j.ctt1ps32xn.7.

Jones, Dalton Anthony. "Louis Armstrong's 'Karnofsky Document': The Reaffirmation of Social Death and the Afterlife of Emotional Labor." Music and Politics 9, no. 1 (Winter 2015). https://doi.org/10.3998/mp.9460447.0009.105.

Judd, Cristle Collins. "Musical Commonplace Books, Writing Theory, and 'Silent Listening': The Polyphonic Examples of the 'Dodecachordon.'” Musical Quarterly 82, no. 3/4 (Autumn-Winter 1998): 482-516. https://doi.org/10.1093/mq/82.3-4.482.

Katriel, Tamar, and Thomas Farrell. "Scrapbooks as Cultural Texts: An American Art of Memory." Text and Performance Quarterly11, no. 1 (January 1991): 1-17. https://doi.org/10.1080/10462939109365990.

Kimball, Marie. "A Playmate of Thomas Jefferson.” The North American Review213, no. 783 (February 1921): 145-56.

Koschnik, Albrecht. "Let a Common Interest Bind Us Together": Associations, Partisanship, and Culture in Philadelphia, 1775-1840. Charlottesville: University of Virginia Press, 2007.

Leonard, Thomas C. News for All: America's Coming-of-Age with the Press. New York: Oxford University Press, 1995. 
30 Music and Politics Winter 2022

Lohman, Laura. Hail Columbia! American Music and Politics in the Early Nation. New York: Oxford University Press, 2020. https://doi.org/10.1093/oso/9780190930615.001.0001.

Lohman, Laura. “'More Truth than Poetry': Parody and Intertextuality in Early American Political Song." MUSICultures 47 (2020): 34-62.

Lohman, Laura. "A Scrapbooking President and a Few Good Tunes: Researching Early American Musical Practices through the Jefferson-Randolph Family Scrapbooks." In Researching Secular Music and Dance in the Early United States: Extending the Legacy of Kate Van Winkle Keller, edited by Laura Lohman, 50-72. New York: Routledge, 2021. https://doi.org/10.4324/9781003039150-4.

Lohman, Laura. "Singing 'Past, Present and Future': Music in Early American Commemoration." Journal of the Society for American Music 15, no. 2 (May 2021): 192-223. https://doi.org/10.1017/S1752196321000031.

Malone, Dumas. Jefferson the President: First Term, 1801-1805. Boston: Little, Brown and Company, 1970.

Malone, Dumas. Jefferson the President: Second Term, 1805-1809. Boston: Little, Brown and Company, 1974.

Manning, Susan. "Naming of Parts; Or, the Comforts of Classification: Thomas Jefferson's Construction of America as Fact and Myth." Journal of American Studies 30, no. 3 (December 1996): 345-64. https://doi.org/10.1017/S0021875800024853.

Mansell, James G. "Musical Modernity and Contested Commemoration at the Festival of Remembrance, 1923-1927." The Historical Journal 52, no. 2 (June 2009): 433-54. https://doi.org/10.1017/S0018246X09007535.

McDonald, Robert M. S. Confounding Father: Thomas Jefferson's Image in His Own Time. Charlottesville: University of Virginia Press, 2016.

McDonald, Robert M. S. "Thomas Jefferson and Historical Self-Construction: The Earth Belongs to the Living?” The Historian, 61, no. 2 (Winter 1999): 289-310. https://doi.org/10.1111/j.1540_ 6563.1999.tb01027.x.

McGill, Meredith L. "Common Places: Poetry, Illocality, and Temporal Dislocation in Thoreau's A Week on the Concord and Merrimack Rivers." American Literary History 19, no. 2 (Summer 2007): 35774. https://doi.org/10.1093/alh/ajm018.

Moreda-Rodríguez, Eva. “Musical Commemorations in Post-Civil War Spain: Joaquín Rodrigo’s Concierto Heroico." In Twentieth-Century Music and Politics: Essays in Memory of Neil Edmunds, edited by Pauline Fairclough, 177-89. New York: Routledge, 2016.

Ndlovu-Gatsheni, Sabelo J., and Wendy Willems. "Making Sense of Cultural Nationalism and the Politics of Commemoration under the Third Chimurenga in Zimbabwe." Journal of Southern African Studies 35, no. 4 (December 2009): 945-65. https://doi.org/10.1080/03057070903314226.

Nelson, Cary. "The Temporality of Commonplaces: A Response to Meredith McGill.” American Literary History 19, no. 2 (Summer 2007): 375-80. https://doi.org/10.1093/alh/ajm004.

Newman, Simon P. Parades and the Politics of the Street: Festive Culture in the Early American Republic. Philadelphia: University of Pennsylvania Press, 1997. https://doi.org/10.9783/9780812200478.

Oberg, Barbara B., ed. 17 February to 30 April 1801. Vol. 33, The Papers of Thomas Jefferson. Princeton, NJ: Princeton University Press, 2018.

O'Connell, John Morgan. Commemorating Gallipoli through Music: Remembering and Forgetting. Lanham, MD: Lexington Books, 2018. 
Ott, Katherine. "Between Person and Profession: The Scrapbooks of Nineteenth-Century Medical Practitioners." In The Scrapbook in American Life, edited by Susan Tucker, Katherine Ott, and Patricia P. Buckler, 29-41. Philadelphia: Temple University Press, 2006.

Paine, Robert Treat. The Works in Verse and Prose of the Late Robert Treat Paine, Jun. Esq. Boston: J. Belcher, 1812.

Rakove, Jack N. "Thomas Jefferson in the Twenty-First Century." In A Companion to Thomas Jefferson, edited by Francis D. Cogliano, 551-65. Malden, MA: Wiley-Blackwell, 2012. https://doi.org/10.1002/9781444344639.ch33.

Ray, William. Horrors of Slavery: or, the American Tars in Tripoli. Troy, NY: Oliver Lyon, 1808.

Ray, William. Poems, on Various Subjects, Religious, Moral, Sentimental and Humorous. Auburn, NY: U. F. Doubleday, 1821.

Rusk, Anna Denov. "Collecting the Confederacy: The Civil War Scrapbook of Henry M. Whitney." Winterthur Portfolio 47, no. 4 (Winter 2013): 267-96. https://doi.org/10.1086/673871.

Scharf, John Thomas, and Thompson Westcott. History of Philadelphia, 1609-1884. Vol. 1. Philadelphia: L. H. Everts \& Company, 1884.

Scofield, Merry Ellen. "The Fatigues of His Table: The Politics of Presidential Dining during the Jefferson Administration." Journal of the Early Republic 26, no. 3 (Fall 2006): 449-69. https://doi.org/10.1353/jer.2006.0055.

Stabile, Susan. Memory's Daughters: The Material Culture of Remembrance in Eighteenth-Century America. Ithaca, NY: Cornell University Press, 2018.

Steffen, Charles G. "Newspapers for Free: The Economies of Newspaper Circulation in the Early Republic." Journal of the Early Republic 23, no. 3 (Autumn 2003): 388-96. https://doi.org/10.2307/3595045.

Stewart, Donald H. The Opposition Press of the Federalist Period. Albany: State University of New York Press, 1969.

Stolba, K. Marie. "Music in the Life of Thomas Jefferson." American Music Teacher 25, no. 5 (April-May 1976): 6-12.

Travers, Len. Celebrating the Fourth: Independence Day and the Rites of Nationalism in the Early Republic. Amherst: University of Massachusetts Press, 1997.

Vermilyea, Peter C. Wicked Litchfield County. Charleston, SC: The History Press, 2016.

Waldstreicher, David. In the Midst of Perpetual Fetes: The Making of American Nationalism, 1776-1820. Chapel Hill: University of North Carolina Press, 1997.

Watson, Amanda. "Shared Reading at a Distance: The Commonplace Books of the Stockton Family, 1812-40.” Book History 18 (2015): 103-33. https://doi.org/10.1353/bh.2015.0006.

Wayland, John W. “The Poetical Tastes of Thomas Jefferson.” Sewanee Review 18, no. 3 (July 1910): 28399.

Wilson, Douglas L. “Thomas Jefferson's Early Notebooks.” The William and Mary Quarterly 42, no. 4 (October 1985): 433-52. https://doi.org/10.2307/1919028.

Wood, Kirsten E. "'Join with Heart and Soul and Voice': Music, Harmony, and Politics in the Early American Republic.” American Historical Review 119, no. 4 (October 2014): 1083-116. https://doi.org/10.1093/ahr/119.4.1083. 
32 Music and Politics Winter 2022

Yang, Hon-Lun. "Power, Politics, and Musical Commemoration: Western Musical Figures in the People's Republic of China 1949-1964." Music and Politics 1, no. 2 (Summer 2007). https://doi.org/10.3998/mp.9460447.0001.205.

Zboray, Ronald J., and Mary Saracino Zboray. "Is It a Diary, Commonplace Book, Scrapbook, or Whatchamacallit?: Six Years of Exploration in New England's Manuscript Archives." Libraries \& the Cultural Record 44, no. 1 (2008): 101-23. https://doi.org/10.1353/lac.0.0055. 